Article

\title{
Evaluation of Suitable Amount of Water and Fertilizer for Mature Grapes in Drip Irrigation in Extreme Arid Regions
}

\author{
Yusheng Hou ${ }^{1,2}$, Zhenhua Wang ${ }^{1,2, *}$, Huaijun Ding ${ }^{3, *}$, Wenhao $\mathrm{Li}^{1,2}$, Yue Wen ${ }^{1,2}$, \\ Jifeng Zhang ${ }^{1,2}$ and Yunqing Dou ${ }^{1,2}$ \\ 1 College of Water \& Architectural Engineering, Shihezi University, Shihezi 832000, China; \\ yushenghou@126.com (Y.H.); 1wh8510012@163.com (W.L.); 17699534686@163.com (Y.W.); \\ federjavan@163.com (J.Z.); adolphmail@163.com (Y.D.) \\ 2 Key Laboratory of Modern Water-Saving Irrigation of Xinjiang Production \& Construction Group, \\ Shihezi University, Shihezi 832000, China \\ 3 Irrigation Center Experimental Station, Xinjiang Production and Construction Corps, \\ Wulumuqi 830000, China \\ * Correspondence: wzh2002027@shzu.edu.cn (Z.W.); sldhj@126.com (H.D.)
}

Received: 27 February 2019; Accepted: 2 April 2019; Published: 7 April 2019

\begin{abstract}
Low water and fertilizer use efficiency have become important factors restricting the sustainable development of agriculture in extreme arid areas, typically like Xinjiang in China. In order to optimize the water and fertilizer management system of grape drip irrigation in the region, field experiments were carried out to study the effects of different water and fertilizer treatments on the physiological growth, yield, and quality of grapes. Meanwhile, principal component analysis, grey correlation analysis, and regression analysis were used to quantify the relative optimal amount of water and fertilizer. The results showed that the effects of water and fertilizer interaction on the photosynthetic index and fluorescence index of grape leaves, in different growth periods, ng reached extremely significant levels $(p<0.01)$. The physiological indicators showed regular changes with the increase and decrease of water and fertilizer use and the appropriate amount of water and fertilizer could maintain the index at a superior level. Meanwhile, there are differences in the index of different growth stages and regular changes with the growth period. The effects of water and fertilizer interaction on the yield, water use efficiency, and quality of drip irrigation reached a very significant level $(p<0.01)$. The yield reached the maximum in W3F2 treatment and the yield increased by $29.76 \%$ compared with the minimum yield of W1F1. The quality index reached a superior level in W3F2 treatment. The results of principal component analysis and grey correlation analysis showed that the optimal water and fertilizer dosage was W3F2 (irrigation $750 \mathrm{~mm}$, fertilization $750 \mathrm{~kg} \mathrm{ha}^{-1}$ ), of which $\mathrm{N}\left(300 \mathrm{~kg} \mathrm{ha}^{-1}\right)-\mathrm{P}_{2} \mathrm{O}_{5}\left(150 \mathrm{~kg} \mathrm{ha}^{-1}\right)-\mathrm{K}_{2} \mathrm{O}\left(300 \mathrm{~kg} \mathrm{ha}^{-1}\right)$, and multiple regression analysis was employed to determine the optimal range of water and fertilizer use is the following: Irrigation volume 725-825 mm and fertilization amount 684-889 $\mathrm{kg} \mathrm{ha}^{-1}$, of which $\mathrm{N}\left(273.6-355.6 \mathrm{~kg} \mathrm{ha}^{-1}\right)$ $\mathrm{P}_{2} \mathrm{O}_{5}\left(136.8-177.8 \mathrm{~kg} \mathrm{ha}^{-1}\right)-\mathrm{K}_{2} \mathrm{O}\left(273.6-355.6 \mathrm{~kg} \mathrm{ha}^{-1}\right)$. The research results can provide a scientific basis for the water and fertilizer management and drip irrigation technology of drip irrigation in seedless white grape fields in extremely arid areas and it is of great significance for the efficient use of regional water and fertilizer resources and the realization of sustainable socio-economic development in the region.
\end{abstract}

Keywords: mature grapes; water and fertilizer management; extreme arid area; comprehensive evaluation; regional agricultural sustainability 


\section{Introduction}

The Tuha area has become a famous production base for melons and fruit in China, due to its natural environmental advantages, such as long illumination time and a large temperature difference between day and night. As the dominant pillar industry in the region, grape planting accounts for $80.3 \%$ of the total area planted with crops. Among them, the planting area of early and late non-nuclear white grapes accounts for $20 \%$ of the country, accounting for more than $60 \%$ of the whole of Xinjiang. It is the largest non-nuclear white grape production base in China and the grape advantage area in the national agricultural product zoning [1,2]. At this stage, large-scale matured irrigation is used in the Tuha area. The irrigation quota is as high as $16,500 \mathrm{~m}^{3} \mathrm{ha}^{-1}$ [3], but the agricultural water saving level is low, water resources are wasted seriously and the ecological water is seriously occupied, and the ecological environment is fragile. It is becoming more and more severe [4]. At the same time, the relevant fertilization system has not been formulated in a targeted manner and there is a lack of scientific and rational fertilization technology to guide the production. A large number of and excessive fertilization conditions are widespread. Irrigation and fertilization are two important factors influencing agricultural production. Appropriate water and fertilizer use can achieve "promoting water with fertilizer and regulating fertilizer with water", so that the synergistic regulation of water and fertilizer can be fully exerted, thereby improving crop yield and quality and water and fertilizer utilization. The purpose of efficiency is of great significance to the sustainable development of agriculture and the protection of the ecological environment in the region and the world [5-7].

In recent years, many scholars have carried out a lot of research on the effects of water and fertilizer coordinated regulation on crop physiology, yield, and quality under drip irrigation conditions, have developed appropriate irrigation and fertilization systems based on crop response indicators, and have obtained many research results, which show that different water and fertilizer dosages can affect crop physiology, yield, and quality, to varying degrees. Appropriate water and fertilizer use can improve crop photosynthetic capacity, water and fertilizer use efficiency, yield, and quality [8-12]. Under normal irrigation conditions, the increase in the amount of fertilization can maintain the maximum photochemical yield and photosystem II (PSII) potential photochemical efficiency of the leaves at a higher level, which leads to the increase of the proportion of the open part of the PSII reaction center, thereby increasing the apparent electron transport rate and the actual photochemical quantum efficiency of PSII. This achieves the goal of improving crop photosynthesis [13]. At present, in the experimental research, the optimal water and fertilizer treatments, according to the crop response index, are mostly based on principal component analysis and gray correlation methods. Some scholars use two methods to quantitatively analyze the optimal water and fertilizer treatment of greenhouse green peppers [14], greenhouse tomatoes [15], lettuce [16], and cucumbers [17]. The research results are in line with actual production. Since, in the actual production, the optimal water and fertilizer dosage for each evaluation index may appear in two treatments, some scholars use the regression analysis method combined with the spatial analysis method to determine the optimum water and fertilizer application range of cucumbers [18], greenhouse tomatoes [19], and cauliflower [20]. The research results have a guiding significance for actual production. Although some scholars have studied the effects of water and fertilizer coupling on crop physiology, yield, and quality, no studies have shown the effect of water and fertilizer coupling on the related indicators of drip irrigation of seedless white grapes, especially in extreme arid regions. At the same time, some scholars have used the principal component analysis, gray correlation analysis, and regression analysis to obtain some results in determining the amount of water and fertilizer in crops. However, the above methods are not used in the research for the calculation and analysis, which makes the results have certain limitations.

On this basis, field experiments were carried out to study the effects of different water and fertilizer treatments on the physiology, yield, and quality of drip irrigation grapes in extreme arid areas. Principal component analysis, grey correlation analysis, and regression analysis were used to quantify the amount of water and fertilizer, based on the response indicators. The main purpose of this study is to explore the optimal water and fertilizer combination model with high yield and high 
efficiency and provide a theoretical basis and technical support for grape drip irrigation water and fertilizer management in extremely arid areas.

\section{Materials and Methods}

\subsection{Experimental Site}

The experiment was carried out in the Hami District Irrigation Experimental Station of the 13th Division of the Xinjiang Production and Construction Corps from April to October 2018 ( $93^{\circ} 37^{\prime} 22^{\prime \prime}$ E, $42^{\circ} 41^{\prime} 57^{\prime \prime} \mathrm{N}$ ). The area is located in the mid-latitude of the Eurasian hinterland, the easternmost part of the Xinjiang Uygur Autonomous Region, affected by the control of the westerly belt and is a typical temperate continental arid climate. The main weather conditions in the area are the following: Dry and less rain, large temperature differences, annual average temperature of $9.8^{\circ} \mathrm{C}$, an annual precipitation of $33.8 \mathrm{~mm}$, an annual evaporation of $3300 \mathrm{~mm}$, an annual average sunshine of $3358 \mathrm{~h}$, an annual total solar radiation of $6397.35 \mathrm{MJ} / \mathrm{m}^{2}, \geq 10^{\circ} \mathrm{C}$ accumulated temperature of $4058.3^{\circ} \mathrm{C}$, and a frost-free period $182 \mathrm{~d}$. The annual average wind speed is 2.3 to $4.9 \mathrm{~m} / \mathrm{s}$ and the easterly wind is prevailing. The groundwater depth of the test site is greater than $8.0 \mathrm{~m}$ and the irrigation water source uses groundwater. The basic physical and chemical properties of the test soil $(0-80 \mathrm{~cm})$ in the test station are shown in Table 1.

Table 1. Basic physical and chemical properties of the tested soil.

\begin{tabular}{|c|c|c|c|c|c|c|c|}
\hline $\begin{array}{l}\text { Soil Layer } \\
\quad(\mathrm{cm})\end{array}$ & Soil Type & $\begin{array}{l}\text { Field Moisture } \\
\text { Capacity }(\%)\end{array}$ & $\begin{array}{c}\text { Soil Bulk } \\
\text { Density } \\
\left(\mathrm{g} \cdot \mathrm{cm}^{-3}\right)\end{array}$ & $\begin{array}{c}\text { Organic } \\
\text { Matter } \\
\left(\mathrm{g} \cdot \mathrm{kg}^{-1}\right)\end{array}$ & $\begin{array}{c}\text { Total N } \\
\left(\mathrm{g} \cdot \mathrm{kg}^{-1}\right)\end{array}$ & $\begin{array}{c}\text { Available } P \\
\left(\mathrm{mg} \cdot \mathrm{kg}^{-1}\right)\end{array}$ & $\begin{array}{c}\text { Available K } \\
\left(\mathrm{mg} \cdot \mathrm{kg}^{-1}\right)\end{array}$ \\
\hline $0-20$ & Sand & $17.52 \pm 0.05$ & $1.58 \pm 0.03$ & 10.52 & 0.51 & 22.09 & 215.54 \\
\hline $20-40$ & Loamy sand & $18.34 \pm 0.03$ & $1.56 \pm 0.04$ & 8.53 & 0.49 & 20.23 & 141.25 \\
\hline $40-60$ & Loamy sand & $18.22 \pm 0.04$ & $1.54 \pm 0.03$ & 9.09 & 0.50 & 22.45 & 152.41 \\
\hline $60-80$ & Sand & $17.92 \pm 0.03$ & $1.60 \pm 0.07$ & 7.86 & 0.47 & 17.66 & 192.55 \\
\hline
\end{tabular}

\subsection{Field Experiment Layout}

The field district experiment was carried out with the 15a (2003 planted) mature seedless white grape vine in the Hami District Irrigation Experimental Station of the 13th Division of the Xinjiang Production and Construction Corps. The grape planting was carried out by local small scaffolding cultivation, a large ditch planting mode, and the ditch. The length is $40 \mathrm{~m}$, the groove width is 1.0 $\mathrm{m}$, and the groove depth is $0.5 \mathrm{~m}$. The grape plant spacing is $1.0 \mathrm{~m}$ and the row spacing is $5.0 \mathrm{~m}$. The test plot size is $40 \mathrm{~m}$ long and $6.0 \mathrm{~m}$ wide. The plot area is $240 \mathrm{~m}^{2}$ and the planting density is 80 plants/zone. The drip irrigation belt laying mode adopts 1 row and 3 tubes, that is, one drip irrigation belt is arranged at the root of the tree and $30 \mathrm{~cm}$ from the root side of the root. The drip irrigation belt is a single-wing labyrinth with an inner diameter of $16 \mathrm{~mm}$ and a wall thickness of $0.18 \mathrm{~mm}$. The spacing is $300 \mathrm{~mm}$, the dripper flow rate is designed as $3.0 \mathrm{~L} / \mathrm{h}$, and the drip irrigation belt working pressure is $0.08-0.10 \mathrm{MPa}$. All districts are equipped with separate water meters and fertilization tanks to control the amount of irrigation and fertilization accurately and the drip irrigation and fertilization are controlled by water and fertilizer integrated equipment.

\subsection{Experiment Design}

In this experiment, the irrigation and fertilization are based on the literature [21,22]. On this basis, two factors of irrigation and fertilization are set up, among which 4 levels of irrigation treatment are provided, as follows: Amounts totaling 600, 675, 750, and $825 \mathrm{~mm}$ (labeled as W1, W2, W3, and W4, respectively); fertilization treatment has 3 levels, 450, 750, and $1050 \mathrm{~kg} \mathrm{ha}^{-1}$ (labeled F1, F2, and F3, respectively), using a $\mathrm{N}: \mathrm{P}_{2} \mathrm{O}_{5}: \mathrm{K}_{2} \mathrm{O}=2: 1: 2$ fertilization ratio. The test was carried out in a completely combined design according to the above treatment levels, with a total of 12 treatments and 3 replicates. The specific test design is shown in Table 2. 
Table 2. Design of experimental treatments.

\begin{tabular}{|c|c|c|c|c|c|}
\hline \multirow{2}{*}{ Treatment } & \multirow{2}{*}{$\begin{array}{c}\text { Irrigation } \\
\text { Amount (mm) }\end{array}$} & \multicolumn{4}{|c|}{ Fertilizer Amount (kg ha $\left.{ }^{-1}\right)$} \\
\hline & & $\mathbf{N}$ & $\mathrm{P}_{2} \mathrm{O}_{5}$ & $\mathrm{~K}_{2} \mathrm{O}$ & Total \\
\hline W1F1 & 600 & 180 & 90 & 180 & 450 \\
\hline W1F2 & 600 & 300 & 150 & 300 & 750 \\
\hline W1F3 & 600 & 420 & 210 & 420 & 1050 \\
\hline W2F1 & 675 & 180 & 90 & 180 & 450 \\
\hline W2F2 & 675 & 300 & 150 & 300 & 750 \\
\hline W2F3 & 675 & 420 & 210 & 420 & 1050 \\
\hline W3F1 & 750 & 180 & 90 & 180 & 450 \\
\hline W3F2 & 750 & 300 & 150 & 300 & 750 \\
\hline W3F3 & 750 & 420 & 210 & 420 & 1050 \\
\hline W4F1 & 825 & 180 & 90 & 180 & 450 \\
\hline W4F2 & 825 & 300 & 150 & 300 & 750 \\
\hline W4F3 & 825 & 420 & 210 & 420 & 1050 \\
\hline
\end{tabular}

The seedless white grape has an obvious period in the whole growth period. According to the growth characteristics of the seedless white grape at different periods, the growth period is divided into six periods, namely, the germination period (16-28 April), new shoot growth period (29 April-28 May), the flowering period (29 May-7 June), the berry growth period ( 8 June-12 July), the berry ripening period (13 July-21 August), the mature period of the vines (22 August-15 September), and the total growth period is $152 \mathrm{~d}$. The principle of irrigation and fertilization is a small number of times and the amount of irrigation and fertilization is the same for each irrigation. When fertilizing, the fertilizer is completely dissolved in the fertilization tank, the water is dripped for 30 minutes before the fertilization, and the fertilization is ended 30 minutes before the water is stopped. See Table 3 for details of irrigation and fertilization treatment at different growth periods.

Table 3. Irrigation and fertilization treatments at different growth periods.

\begin{tabular}{|c|c|c|c|c|c|c|c|c|c|c|}
\hline \multirow{3}{*}{ Growth Period } & \multicolumn{6}{|c|}{ Water Treatment } & \multicolumn{4}{|c|}{ Fertilizer Treatment } \\
\hline & \multicolumn{4}{|c|}{ Irrigation Amount (mm) } & \multirow{2}{*}{$\begin{array}{l}\text { Irrigation } \\
\text { Times }\end{array}$} & \multirow{2}{*}{$\begin{array}{l}\text { Irrigation } \\
\text { Cycle (d) }\end{array}$} & \multicolumn{3}{|c|}{$\begin{array}{l}\text { Fertilizer Amount } \\
\quad\left(\mathrm{kg} \mathrm{ha}^{-1}\right)\end{array}$} & \multirow{2}{*}{$\begin{array}{c}\text { Fertilization } \\
\text { Times }\end{array}$} \\
\hline & W1 & W2 & W3 & W4 & & & F1 & F2 & F3 & \\
\hline Germination period & 25 & 28.125 & 31.25 & 34.375 & 1 & 12 & 45 & 75 & 105 & 1 \\
\hline Shoot growth period & 125 & 140.625 & 156.25 & 171.875 & 5 & 7 & 90 & 150 & 210 & 2 \\
\hline Flowering period & 25 & 28.125 & 31.25 & 34.375 & 1 & 7 & 45 & 75 & 105 & 1 \\
\hline Berry growth period & 200 & 225 & 250 & 275 & 8 & 5 & 180 & 300 & 420 & 4 \\
\hline Berry mature period & 175 & 196.875 & 218.75 & 240.625 & 7 & 5 & 90 & 150 & 210 & 2 \\
\hline Branch mature period & 50 & 56.25 & 62.5 & 68.75 & 2 & 12 & 0 & 0 & 0 & 0 \\
\hline Whole growth period & 600 & 675 & 750 & 825 & 24 & 152 & 450 & 750 & 1050 & 10 \\
\hline
\end{tabular}

\subsection{Measurements and Methods Applied}

\subsubsection{Photosynthetic Index}

The measurement work was carried out in a clear and cloudless day during different growth periods, in this study, 22 May (shoot growth period), 5 June (flowering period), 30 June (berry growth period, and 4 August (berry ripening period), were selected and the CI-340 handheld photosynthesis measurement system, produced by American CID Company, was adopted. The samples were collected from a well-developed and uniform plant with, from 10:00 to 12:00, and weight of 5-7 pieces of new shoot tips that grow uniformly were then measured. Measurement calculation items include net photosynthetic rate $\left(P_{n}\right)$, transpiration rate $\left(T_{r}\right)$, stomatal conductance $\left(G_{s}\right)$, and intercellular $\mathrm{CO}_{2}$ concentration $\left(C_{i}\right)$. During the measurement, 3 sets of stable data were collected from each group of leaves continuously, of which the average value was used as the processing photosynthetic index data. 


\subsubsection{Fluorescence Index}

The determination of the fluorescence parameters in the four growth periods and the determination of the photosynthesis index was carried out simultaneously and the functional leaves were selected in accordance with the photosynthetic index. The chlorophyll fluorescence parameters were determined using a PAM-2500 portable chlorophyll fluorescence measurement system, manufactured by WALZ, Germany. The initial fluorescence $\left(F_{0}\right)$ was measured with weakly measured light before dawn (04:00) on the day of the measurement date, followed by saturation pulsed light treatment $\left(6000 \mu \mathrm{mol} \cdot \mathrm{m}^{-2} \cdot \mathrm{s}^{-1}\right.$, pulse time $\left.0.8 \mathrm{~s}\right)$ to determine the maximum fluorescence $\left(F_{m}\right)$. The initial fluorescence $\left(F_{0}\right)$ and maximum fluorescence $\left(F_{m}\right)$ of the corresponding treated leaves were manually input before determining the chlorophyll fluorescence parameters under natural light conditions. The steady-state fluorescence $\left(F_{s}\right)$ was measured with natural light as actinic light between 10:00 and 12:00, and then the saturation pulse $\left(6000 \mu \mathrm{mol} \cdot \mathrm{m}^{-2} \cdot \mathrm{s}^{-1}\right.$, pulse time $\left.0.8 \mathrm{~s}\right)$ was turned on to determine the maximum response fluorescence $\left(\mathrm{Fm}^{\prime}\right)$ of the corresponding treatment light. Then, the far infrared light was turned on $\left(6-7 \mu \mathrm{mol} \cdot \mathrm{m}^{-2} \cdot \mathrm{s}^{-1}\right.$ for $\left.6 \mathrm{~s}\right)$ to measure the minimum fluorescence $\left(F_{0}{ }^{\prime}\right)$ for one transient illumination. According to the above-measured data, refer to the corresponding calculation methods to calculate the original photochemistry maximum yield $\left(F_{v} / F_{m}\right)$, photochemical quenching coefficient $\left(q^{P}\right)$, and PSII actual photochemical quantum efficiency (ФPSII). The specific formulas are as follows $[23,24]$ :

$$
\begin{gathered}
F_{v} / F_{m}=\left(F_{m}-F_{0}\right) / F_{m}, \\
q^{P}=\left(F_{m}{ }^{\prime}-F s\right) /\left(F_{m}{ }^{\prime}-F_{0}{ }^{\prime}\right), \\
\text { ФPSII }=\left(F_{m}{ }^{\prime}-F_{s}\right) / F_{m}{ }^{\prime}
\end{gathered}
$$

where $F_{v}$ is the maximum variable fluorescence in the dark adaptation state.

\subsubsection{Yield and Quality}

Grape yield was measured with 5 plants in each plot during the ripening period of the berries and averaged, then converted to hectare yield.

After measuring the output, $500 \mathrm{~g}$ of fresh grape samples were taken and and entrusted to the Agricultural and Rural Agricultural Quality Supervision and Inspection Center (Shihezi) to determine the soluble solids and titrate the acid and vitamin $C$ quality indexes.

\subsubsection{Irrigation Water, Fertilizer Utilization Efficiency and Yield Increase Effect}

The iWUE is calculated as follows [25]:

$$
i W U E=Y / I
$$

where $\mathrm{Y}$ is the grape yield $\left(\mathrm{kg} \mathrm{ha}^{-1}\right)$ and $\mathrm{I}$ is the irrigation quota $\left(\mathrm{m}^{3} \cdot \mathrm{ha}^{-1}\right)$.

The PFP is calculated as follows [26]:

$$
P F P=Y / F
$$

where $\mathrm{Y}$ is the grape yield $\left(\mathrm{kg} \mathrm{ha}^{-1}\right)$, and $\mathrm{F}$ is the amount of fertilizer $\left(\mathrm{kg} \mathrm{ha}^{-1}\right)$.

The $E_{i}$ is calculated as follows [27]:

$$
E_{i}=\left(Y_{X}-Y_{L}\right) / Y_{L}
$$

where $Y_{X}$ is the yield of a certain water and fertilizer treatment $\left(\mathrm{kg} \mathrm{ha}^{-1}\right)$ and $Y_{L}$ is the yield of W1F1 water and fertilizer treatment $\left(\mathrm{kg} \mathrm{ha}^{-1}\right)$. 


\subsubsection{Principal Component Analysis}

The principal component analysis of this paper is carried out by MATLAB, specifically as follows:

$\mathrm{A}=\operatorname{xlsread}\left(\right.$ 'data.$\left.x l s x^{\prime}\right) ; \%$ Open the data and assign the data to matrix A

$\mathrm{x}=\mathrm{zscore}(\mathrm{A}) ; \%$ Standardized data

[coeff, score, latent, tsquare] $=$ princomp $(\mathrm{x}) ; \%$ Call principal component analysis

latent'; \% Calculated eigenvalue

$\mathrm{y}=(100 * \text { latent } / \operatorname{sum}(\text { latent }))^{\prime} ; \%$ Calculated contribution rate

According to the contribution rate, calculated by the MATLAB program, the principal component evaluation value is calculated by taking the cumulative contribution rate $\geq 85 \%$ as the principal component standard.

$$
Z_{k}=r_{k 1} x_{1}+r_{k 2} x_{2}+\ldots \ldots+r_{k m} x_{m}(k<m)
$$

where $m=8, Z_{k}$ is the principal component evaluation value, $r_{k m}$ is the component coefficient (Computation by MATLAB), and $x_{m}$ is the normalized value of each response index (Computation by MATLAB).

The comprehensive evaluation value is calculated, based on the two principal component evaluation values, as follows:

$$
Z=y 1 Z_{1}+y 2 Z_{2}+\ldots \ldots y n Z k(n=k)
$$

where $Z$ is the comprehensive evaluation value, $Z_{k}$ is the principal component evaluation value, and $y_{n}$ is the contribution ratio corresponding to the principal component (Computation by MATLAB).

\subsubsection{Grey Correlation Analysis}

The grey correlation analysis of this paper is carried out by MATLAB, specifically as follows:

$[$ data, name $]=x \operatorname{xread}\left({ }^{\prime}\right.$ data.$x l s x^{\prime}$, , sheet1',' A1 : M8'); \% Open raw data

zxlNum $=12 ; \%$ Subsequence number $\mathrm{i}(\mathrm{n})$

$\mathrm{zbNum}=8 ; \%$ Number of indexs $\mathrm{k}(\mathrm{n})$

rou $=0.5 ; \%$ Discriminant coefficient

aveData $=$ mean $($ data $) ; \%$ Average of each column

for $\mathrm{i}=1: \mathrm{zbNum}$

$\operatorname{newData}(\mathrm{i},:)=\operatorname{data}(\mathrm{i},:)$./aveData; \% Non - dimensionalized sequence data

end

for $\mathrm{i}=2:$ zxlNum +1

$\operatorname{diff}(:, \mathrm{i}-1)=\operatorname{abs}($ newData $(:, 1)-\operatorname{newData}(:, \mathrm{i})) ; \%$ Range

end

$\operatorname{maxDiffxl}=\max ($ diff $) ; \%$ Row vector consisting of the maximum range of each column

$\operatorname{minDiffxl}=\min ($ diff $) ; \%$ Row vector consisting of the minimum range of each column

for $\mathrm{i}=1: \mathrm{zbNum}$

for $j=1:$ zxlNum

correlation $(\mathrm{i}, \mathrm{j})=(\operatorname{minDiffxl}(\mathrm{j})+\operatorname{rou} * \max \operatorname{Diffxl}(\mathrm{j})) /(\operatorname{diff}(\mathrm{i}, \mathrm{j})+\operatorname{rou} * \max \operatorname{Diffxl}(\mathrm{j}))$;

$\%$ Correlation coefficient

end

end

correlationNew $=$ mean $($ correlation $) ; \%$ Average correlation degree 


\subsubsection{Data Normalization}

The data of each response index of grape drip irrigation is calculated using the linear normalization (Min-Max normalization) [28], as follows:

$$
X_{\text {norm }}=\frac{X-X_{\min }}{X_{\max }-X_{\min }}
$$

where $X_{\text {norm }}$ is the normalized value; $X$ is the raw data that needs to be normalized; and $X_{\min }$ and $X_{\max }$ denote the minimum and maximum value of the original data.

\section{Results and Analysis}

\subsection{Effect of Water and Fertilizer Dosage on Photosynthesis Index of Drip Irrigation Grapes}

\subsubsection{Effects of Water and Fertilizer Application Rate on $P_{n}$ and $T_{r}$ of Drip Irrigation Grape Leaves}

The regularity and variance analysis of net photosynthetic rate $\left(P_{n}\right)$ and transpiration rate $\left(T_{r}\right)$ are shown in Table 4. See from Table 4, the effects of water and fertilizer interaction, irrigation single factor on $P_{n}$ and $T_{r}$ of grape leaves under drip irrigation at different growth stages reached a very significant level $(p<0.01)$.

It is observable in Table 4 that the $P_{n}$ of the drip irrigation grape leaves reached the highest level in the berry growth period and the average value of each water and fertilizer treatment was 29.73 $\mu \mathrm{mol} \cdot \mathrm{m}^{-2} \cdot \mathrm{s}^{-1}$, the lowest level in the shoot growth period and the average value of water and fertilizer treatments was $12.58 \mu \mathrm{mol} \cdot \mathrm{m}^{-2} \cdot \mathrm{s}^{-1}$, with the promotion of the growth period, with the overall trend increasing and then decreasing. Under different fertility treatments, the $P_{n}$ of drip-irrigated grape leaves, under different fertility treatments, showed that under the same fertilization conditions, the $P_{n}$ of grape leaves increased with the increase of the irrigation amount. Under the same irrigation condition, the grape leaves' $P_{n}$ increased first and then decreased with the increase of the fertilization amount. Under the condition of water and fertilizer interaction, the maximum value of $P_{n}$ in grape leaves appeared in W4F2 treatment and the minimum appeared in W1F1 treatment. There was no significant difference between W3F2 treatment and W4F2 treatment at each growth period $(p>$ 0.05). There were obvious regularity changes of the $P_{n}$ in leaves under different water and fertilizer treatment conditions.

It can also be seen from Table 4 that the drip-filled grape leaves' $T_{r}$ reached the highest level in the berry growth period and the average value of each water and fertilizer treatment was 5.63 $\mathrm{mmol} \cdot \mathrm{m}^{-2} \cdot \mathrm{s}^{-1}$, which was at the lowest level in the new shoot growth period. The average value of each water and fertilizer treatment was $3.51 \mathrm{mmol} \cdot \mathrm{m}^{-2} \cdot \mathrm{s}^{-1}$, which tends to increase first and then decrease with the growth of the growth period. Under different fertility treatments, the $T_{r}$ of drip irrigation grape leaves, under different fertility treatments, showed that, under the same fertilization conditions, the $T_{r}$ of grape leaves increased with the increase of irrigation amount. Under the same irrigation condition, under W1 and W2 irrigation levels, the grape leaves' $T_{r}$ increased with the increase of the fertilization amount. Under W3 and W4 irrigation levels, the grape leaves' $T_{r}$ increased first and then decreased with the increase of the fertilization amount, that is, under the condition of water and fertilizer interaction, the maximum value of grape leaves' $T_{r}$ appeared in the W4F2 treatment and the minimum value appeared in the W1F1 treatment and there was no significant difference between W3F2 treatment and W4F2 treatment in each growth period $(p>0.05)$. There were obvious regularity changes of the leaf $T_{r}$ under different water and fertilizer treatment conditions.

In summary, a reasonable amount of water and fertilizer can reduce the abscisic acid content of grape leaves and increase the content of cytokinin and auxin, thereby increasing the $P_{n}$ and $T_{r}$ of drip irrigation grape leaves. 
Table 4. Effect of water and fertilizer application on the $P_{n}$ and $T_{r}$ of drip irrigation grape leaves.

\begin{tabular}{|c|c|c|c|c|c|c|c|c|}
\hline \multirow[b]{2}{*}{ Treatment } & \multicolumn{4}{|c|}{$P_{n}\left(\mu \mathrm{mol} \cdot \mathrm{m}^{-2} \cdot \mathrm{s}^{-1}\right)$} & \multicolumn{4}{|c|}{$T_{r}\left(\mathrm{mmol} \cdot \mathrm{m}^{-2} \cdot \mathrm{s}^{-1}\right)$} \\
\hline & $\begin{array}{c}\text { Shoot Growth } \\
\text { Period }\end{array}$ & $\begin{array}{l}\text { Flowering } \\
\text { Period }\end{array}$ & $\begin{array}{l}\text { Berry Growth } \\
\text { Period }\end{array}$ & $\begin{array}{c}\text { Berry Mature } \\
\text { Period }\end{array}$ & $\begin{array}{c}\text { Shoot Growth } \\
\text { Period }\end{array}$ & $\begin{array}{l}\text { Flowering } \\
\text { Period }\end{array}$ & $\begin{array}{l}\text { Berry Growth } \\
\text { Period }\end{array}$ & $\begin{array}{l}\text { Berry Mature } \\
\text { Period }\end{array}$ \\
\hline W1F1 & $10.06 \pm 0.06 \mathrm{~g}$ & $14.92 \pm 0.16 \mathrm{~h}$ & $25.00 \pm 0.04 \mathrm{~h}$ & $19.25 \pm 0.07 \mathrm{~h}$ & $3.09 \pm 0.06 \mathrm{~h}$ & $4.12 \pm 0.03 \mathrm{~h}$ & $5.27 \pm 0.10 \mathrm{~h}$ & $4.66 \pm 0.04 h$ \\
\hline W1F2 & $11.23 \pm 0.03 \mathrm{f}$ & $16.04 \pm 0.08 \mathrm{~g}$ & $25.80 \pm 0.07 \mathrm{~g}$ & $21.00 \pm 0.04 \mathrm{~g}$ & $3.17 \pm 0.04 \mathrm{gh}$ & $4.19 \pm 0.13 \mathrm{gh}$ & $5.32 \pm 0.03 \mathrm{gh}$ & $4.72 \pm 0.03 \mathrm{gh}$ \\
\hline W1F3 & $10.92 \pm 0.13 \mathrm{f}$ & $15.91 \pm 0.06 \mathrm{~g}$ & $25.23 \pm 0.04 h$ & $19.56 \pm 0.06 h$ & $3.24 \pm 0.08 \mathrm{~g}$ & $4.27 \pm 0.10 \mathrm{fg}$ & $5.41 \pm 0.01 \mathrm{fg}$ & $4.79 \pm 0.06 f g$ \\
\hline $\mathrm{W} 2 \mathrm{~F} 1$ & $11.71 \pm 0.16 \mathrm{e}$ & $17.02 \pm 0.28 \mathrm{f}$ & $27.93 \pm 0.18 \mathrm{f}$ & $21.89 \pm 0.01 \mathrm{f}$ & $3.36 \pm 0.06 \mathrm{f}$ & $4.36 \pm 0.08 \mathrm{ef}$ & $5.48 \pm 0.06 \mathrm{ef}$ & $4.85 \pm 0.07 \mathrm{ef}$ \\
\hline $\mathrm{W} 2 \mathrm{~F} 2$ & $12.66 \pm 0.21 \mathrm{~d}$ & $18.84 \pm 0.41 \mathrm{~d}$ & $30.55 \pm 0.07 \mathrm{e}$ & $24.21 \pm 0.44 \mathrm{~d}$ & $3.42 \pm 0.03 \mathrm{ef}$ & $4.41 \pm 0.01 \mathrm{ef}$ & $5.54 \pm 0.06 \mathrm{e}$ & $4.89 \pm 0.01 \mathrm{ef}$ \\
\hline W2F3 & $11.75 \pm 0.23 \mathrm{e}$ & $17.79 \pm 0.14 \mathrm{e}$ & $28.09 \pm 0.13 f$ & $23.24 \pm 0.62 \mathrm{e}$ & $3.51 \pm 0.01 \mathrm{de}$ & $4.49 \pm 0.04 \mathrm{de}$ & $5.60 \pm 0.04 \mathrm{de}$ & $4.91 \pm 0.03 \mathrm{e}$ \\
\hline W3F1 & $12.68 \pm 0.03 \mathrm{~d}$ & $19.01 \pm 0.27 \mathrm{~d}$ & $30.98 \pm 0.03 d$ & $23.43 \pm 0.04 \mathrm{e}$ & $3.57 \pm 0.10 \mathrm{~cd}$ & $4.62 \pm 0.03 c d$ & $5.68 \pm 0.03 c d$ & $5.03 \pm 0.10 \mathrm{~d}$ \\
\hline W3F2 & $14.38 \pm 0.08 \mathrm{a}$ & $22.95 \pm 0.06 a$ & $33.27 \pm 0.04 a$ & $27.86 \pm 0.06 a$ & $3.82 \pm 0.03 a$ & $4.89 \pm 0.04 a$ & $5.95 \pm 0.07 a$ & $5.31 \pm 0.01 a$ \\
\hline W3F3 & $13.27 \pm 0.23 c$ & $20.00 \pm 0.06 c$ & $31.98 \pm 0.11 c$ & $25.28 \pm 0.03 c$ & $3.64 \pm 0.06 b c$ & $4.70 \pm 0.04 b c$ & $5.73 \pm 0.04 c$ & $5.11 \pm 0.03 \mathrm{~cd}$ \\
\hline W4F1 & $13.82 \pm 0.27 b$ & $21.52 \pm 0.42 b$ & $32.00 \pm 0.16 c$ & $25.55 \pm 0.07 c$ & $3.71 \pm 0.01 \mathrm{ab}$ & $4.74 \pm 0.06 \mathrm{bc}$ & $5.79 \pm 0.01 b c$ & $5.17 \pm 0.03 b c$ \\
\hline W4F2 & $14.41 \pm 0.01 \mathrm{a}$ & $23.01 \pm 0.04 \mathrm{a}$ & $33.45 \pm 0.07 a$ & $27.90 \pm 0.08 \mathrm{a}$ & $3.83 \pm 0.04 \mathrm{a}$ & $4.90 \pm 0.06 a$ & $5.97 \pm 0.10 \mathrm{a}$ & $5.33 \pm 0.04 a$ \\
\hline W4F3 & $14.03 \pm 0.04 b$ & $21.87 \pm 0.18 b$ & $32.50 \pm 0.17 \mathrm{~b}$ & $26.70 \pm 0.14 b$ & $3.77 \pm 0.03 a$ & $4.80 \pm 0.03 \mathrm{ab}$ & $5.86 \pm 0.03 \mathrm{ab}$ & $5.23 \pm 0.03 \mathrm{ab}$ \\
\hline \multicolumn{9}{|c|}{ Two-factor analysis of variance ( $F$ value analysis) } \\
\hline $\mathrm{W}$ & $43.004^{* *}$ & $40.827^{* *}$ & $80.635^{* *}$ & $30.823^{* *}$ & $55.166^{* *}$ & $52.093^{* *}$ & $38.383^{* *}$ & $44.068^{* *}$ \\
\hline $\mathrm{F}$ & 1.251 & 1.191 & 0.697 & 1.869 & 0.563 & 0.544 & 0.724 & 0.699 \\
\hline $\mathrm{W} \times \mathrm{F}$ & $183.907^{* *}$ & $320.043^{* *}$ & $1759.637^{* *}$ & $356.471^{* *}$ & $47.742 * *$ & $37.370 * *$ & $35.846^{* *}$ & 48.722 ** \\
\hline
\end{tabular}

Note: The values are "mean \pm standard error". Different lowercase letters in the same column indicate significant difference between treatments $(p<0.05) ;{ }^{*}$ indicates significant difference

at $p=0.05$ level, and ${ }^{* *}$ indicates significant difference at $p=0.01$ level. The same below. 


\subsubsection{Effects of Water and Fertilizer Application on $G_{s}$ and $C_{i}$ in Drip Irrigation Grape Leaves}

The regularity and variance analysis of stomatal conductance $\left(G_{s}\right)$ and intercellular $\mathrm{CO}_{2}$ concentration $\left(C_{i}\right)$ are shown in Table 5. As shown in Table 5, the effects of water and fertilizer interaction, irrigation single factor on the $G_{s}$ and $C_{i}$ of grape leaves under drip irrigation at different growth stages reached a very significant level $(p<0.01)$.

It can be seen from Table 5 that the $G_{S}$ of the drip-filled grape leaves reached the highest level in the berry growth period and the average value of each water and fertilizer treatment was 282.82 $\mathrm{mmol} \cdot \mathrm{m}^{-2} \cdot \mathrm{s}^{-1}$, which was at the lowest level in the new shoot growth period. The average value of each water and fertilizer treatment was $126.24 \mathrm{mmol} \cdot \mathrm{m}^{-2} \cdot \mathrm{s}^{-1}$, with the promotion of the growth period, the overall trend of increasing and then decreasing. Under different fertility treatments, the $G_{s}$ of drip-irrigated grape leaves, under different fertility treatments, showed that, under the same fertilization conditions, the $G_{S}$ of grape leaves increased with the increase of irrigation amount. Under the same irrigation condition, grape leaves' $G_{S}$ increased first and then decreased with the increase of the fertilization amount. Under the condition of water and fertilizer interaction, the maximum value of $G_{s}$ in grape leaves appeared in theW4F2 treatment and the minimum value appears in the W1F1 treatment. In each growth period, there was no significant difference between W3F2 treatment and W4F2 treatment $(p>0.05)$. There were obvious regularity changes of $G_{s}$ in leaves under different water and fertilizer treatment conditions, indicating that $G_{s}$ can better reflect the water and fertilizer deficit of drip irrigation.

It can also be seen from Table 5 that the $C_{i}$ of the drip irrigation grape leaves reached the highest level in the shoot growth period, the average value of each water and fertilizer treatment was 305.87 $\mu \mathrm{mol} \cdot \mathrm{m}^{-2} \cdot \mathrm{s}^{-1}$, which was at the lowest level in the berry growth period, and the average value of each water and fertilizer treatment was $148.19 \mu \mathrm{mol} \cdot \mathrm{m}^{-2} \cdot \mathrm{s}^{-1}$. This was the opposite to the change of $P_{n}, T_{r}$ and $G_{s}$ with the growth period. Under different fertility treatments, the grape leaves of the drip irrigation grape showed that, under the same fertilization conditions, the $C_{i}$ of the grape leaves decreased with the increase of irrigation amount. Under the same irrigation condition, the grape leaves' $C_{i}$ first decreased and then increased with the increase of the fertilization amount. Under the condition of water and fertilizer interaction, the maximum value of grape leaf $C_{i}$ appears in the W1F1 treatment and the minimum value appears in the W4F2 treatment. There are obvious regularity changes of $C_{i}$ in leaves under different water and fertilizer treatment conditions, indicating that $C_{i}$ can also reflect the water and fertilizer deficit of drip irrigation.

In summary, reasonable water and fertilizer use can promote the evapotranspiration of water and the migration of mineral elements, reduce the activity of nitrate reductase, increase the chlorophyll content and the accumulation of carbohydrates in vascular sheath cells to improve the gas exchange capacity of grape leaves, and finally affect the photosynthetic carbonization ability of grapes.

\subsection{Effect of Water and Fertilizer Dosage on Grape Fluorescence Index}

\subsubsection{Effects of Water and Fertilizer Application on $F_{v} / F_{m}$ of Drip-irrigated Grape Leaves}

The effects of different water and fertilizer treatments on the original photochemistry maximum yield $\left(F_{v} / F_{m}\right)$ of drip-irrigated grape leaves at different growth stages are shown in Table 6 . The effects of water and fertilizer interaction, fertilization single factor on $F_{v} / F_{m}$ of grape leaves under drip irrigation, at different growth stages reached a very significant level $(p<0.01)$. 
Table 5. Effects of water and fertilizer application on the $G_{s}$ and $C_{i}$ in drip irrigation grape leaves.

\begin{tabular}{|c|c|c|c|c|c|c|c|c|}
\hline \multirow[b]{2}{*}{ Treatment } & \multicolumn{4}{|c|}{$G_{s}\left(\mathrm{mmol} \cdot \mathrm{m}^{-2} \cdot \mathrm{s}^{-1}\right)$} & \multicolumn{4}{|c|}{$C_{i}\left(\mu \mathrm{mol} \cdot \mathrm{mol}^{-1}\right)$} \\
\hline & $\begin{array}{l}\text { Shoot Growth } \\
\text { Period }\end{array}$ & $\begin{array}{l}\text { Flowering } \\
\text { Period }\end{array}$ & $\begin{array}{l}\text { Berry Growth } \\
\text { Period }\end{array}$ & $\begin{array}{l}\text { Berry Mature } \\
\text { Period }\end{array}$ & $\begin{array}{l}\text { Shoot Growth } \\
\text { Period }\end{array}$ & $\begin{array}{l}\text { Flowering } \\
\text { Period }\end{array}$ & $\begin{array}{l}\text { Berry Growth } \\
\text { Period }\end{array}$ & $\begin{array}{l}\text { Berry Mature } \\
\text { Period }\end{array}$ \\
\hline W1F1 & $101.32 \pm 0.96 \mathrm{~g}$ & $156.31 \pm 0.98 \mathrm{~h}$ & $223.47 \pm 0.66 \mathrm{i}$ & $185.62 \pm 2.29 j$ & $354.45 \pm 2.05 a$ & $285.76 \pm 2.49 a$ & $190.97 \pm 5.70 a$ & $238.47 \pm 2.07 \mathrm{a}$ \\
\hline W1F2 & $115.21 \pm 0.30 \mathrm{ef}$ & $177.23 \pm 3.92 f$ & $252.76 \pm 1.07 \mathrm{~g}$ & $210.39 \pm 1.97 \mathrm{~h}$ & $330.04 \pm 2.88 c$ & $260.44 \pm 2.21 c$ & $163.75 \pm 1.06 \mathrm{de}$ & $220.71 \pm 5.24 b$ \\
\hline W1F3 & $108.57 \pm 2.02 \mathrm{fg}$ & $165.38 \pm 6.53 \mathrm{~g}$ & $241.14 \pm 1.61 \mathrm{~h}$ & $198.67 \pm 3.78 \mathrm{i}$ & $342.35 \pm 6.15 b$ & $272.85 \pm 5.44 b$ & $176.22 \pm 1.73 b$ & $231.55 \pm 5.02 \mathrm{a}$ \\
\hline W2F1 & $116.77 \pm 3.15 \mathrm{ef}$ & $182.45 \pm 3.46 \mathrm{f}$ & $263.87 \pm 5.47 f$ & $225.97 \pm 8.44 \mathrm{~g}$ & $336.67 \pm 3.78 b c$ & $268.46 \pm 0.65 b$ & $173.56 \pm 5.03 b c$ & $220.72 \pm 6.67 \mathrm{~b}$ \\
\hline W2F2 & $127.15 \pm 1.20 \mathrm{~cd}$ & $215.38 \pm 0.54 \mathrm{~cd}$ & $294.61 \pm 0.86 \mathrm{~cd}$ & $250.00 \pm 2.83 \mathrm{de}$ & $301.21 \pm 5.95 \mathrm{ef}$ & $236.78 \pm 2.52 \mathrm{e}$ & $156.32 \pm 4.70 \mathrm{e}$ & $195.99 \pm 2.81 d$ \\
\hline W2F3 & $120.23 \pm 0.33 \mathrm{de}$ & $198.76 \pm 1.75 \mathrm{e}$ & $278.09 \pm 0.13 \mathrm{e}$ & $235.47 \pm 6.32 \mathrm{f}$ & $321.15 \pm 4.45 \mathrm{~d}$ & $248.78 \pm 3.93 \mathrm{~d}$ & $167.88 \pm 4.07 \mathrm{~cd}$ & $208.77 \pm 1.08 c$ \\
\hline W3F1 & $126.99 \pm 1.43 \mathrm{~cd}$ & $207.65 \pm 7.99 d$ & $288.69 \pm 5.22 d$ & $242.79 \pm 3.95 \mathrm{ef}$ & $302.88 \pm 2.66 \mathrm{e}$ & $243.84 \pm 5.43 \mathrm{~d}$ & $148.29 \pm 3.24 f$ & $192.14 \pm 1.61 d$ \\
\hline W3F2 & $144.24 \pm 2.49 \mathrm{a}$ & $239.78 \pm 0.31 \mathrm{a}$ & $322.66 \pm 0.93 a$ & $280.96 \pm 1.47 \mathrm{a}$ & $278.87 \pm 1.23 \mathrm{gh}$ & $212.73 \pm 3.86 \mathrm{~g}$ & $120.66 \pm 0.48 \mathrm{~h}$ & $160.34 \pm 4.72 \mathrm{f}$ \\
\hline W3F3 & $133.12 \pm 1.24 b c$ & $218.66 \pm 1.90 c$ & $293.78 \pm 5.35 \mathrm{~cd}$ & $253.41 \pm 0.58 \mathrm{~cd}$ & $294.34 \pm 1.90 \mathrm{f}$ & $228.97 \pm 1.37 f$ & $130.18 \pm 4.50 \mathrm{~g}$ & $182.23 \pm 4.56 \mathrm{e}$ \\
\hline W4F1 & $\begin{array}{c}136.65 \pm \\
11.81 \mathrm{ab}\end{array}$ & $222.23 \pm 3.15 c$ & $300.23 \pm 7.40 c$ & $260.22 \pm 1.10 c$ & $281.23 \pm 1.74 \mathrm{~g}$ & $212.22 \pm 3.14 \mathrm{~g}$ & $134.53 \pm 3.49 \mathrm{~g}$ & $158.63 \pm 5.13 f$ \\
\hline W4F2 & $145.52 \pm 2.15 a$ & $240.32 \pm 0.45 a$ & $323.95 \pm 1.34 \mathrm{a}$ & $283.13 \pm 2.64 a$ & $256.51 \pm 2.14 \mathrm{i}$ & $185.56 \pm 0.79 h$ & $102.42 \pm 2.01 \mathrm{i}$ & $135.54 \pm 2.17 \mathrm{~h}$ \\
\hline W4F3 & $139.06 \pm 4.16 \mathrm{ab}$ & $230.39 \pm 0.55 b$ & $310.55 \pm 2.05 b$ & $270.46 \pm 0.65 b$ & $270.76 \pm 5.32 \mathrm{~h}$ & $206.54 \pm 2.18 \mathrm{~g}$ & $113.51 \pm 2.14 h$ & $147.94 \pm 2.91 \mathrm{~g}$ \\
\hline \multicolumn{9}{|c|}{ Two-factor analysis of variance ( $F$ value analysis) } \\
\hline W & $27.957^{* *}$ & $32.542 * *$ & $32.071^{* *}$ & $35.792 * *$ & $37.461^{* *}$ & $31.915 * *$ & $30.851 * *$ & $57.503 * *$ \\
\hline $\mathrm{F}$ & 1.724 & 1.866 & 1.973 & 1.701 & 1.689 & 2.011 & 1.984 & 1.059 \\
\hline $\mathrm{W} \times \mathrm{F}$ & $25.543^{* *}$ & $128.274^{* *}$ & $160.288^{* *}$ & $140.424^{* *}$ & $138.033^{* *}$ & $178.836^{* *}$ & $122.079 * *$ & $144.658^{* *}$ \\
\hline
\end{tabular}


As an important parameter to measure the photosyntheticity of crops, $F_{v} / F_{m}$ can reflect the quantum yield of all PSII reaction centers when they are open and it is a probe indicating good indicators of stress and photoinhibition [29]. It can be seen from Table 6 that the $F_{v} / F_{m}$ of the drip irrigation grape leaves reached the highest level in the berry growth period and the average value of each water and fertilizer treatment was 0.781 , which was the lowest level in the new shoot growth period and the average value of each water and fertilizer treatment was 0.728. During the growth period, the overall progress of the promotion is firstly increased and then decreased. The $F_{v} / F_{m}$ of drip irrigation grape leaves, under different growth, periods showed that, under the same fertilization conditions, the $F_{v} / F_{m}$ of grape leaves increased with the increase of the irrigation amount. Under the same irrigation condition, the grape leaf $F_{v} / F_{m}$ increased with the increase of fertilization amount, that is, under the interaction of water and fertilizer, the maximum value of the grape leaf $F_{v} / F_{m}$ appeared in the W4F3 treatment and the minimum appeared in the W1F1 treatment. There was no significant difference between the W4F3 and W3F2 and W3F3 in the growth period, except for the shoot growth period $(p>0.05)$.

Table 6. Effects of water and fertilizer application on the $F_{v} / F_{m}$ of drip-irrigated grape leaves.

\begin{tabular}{ccccc}
\hline & \multicolumn{4}{c}{$\boldsymbol{F}_{v} / \boldsymbol{F}_{\boldsymbol{m}}$} \\
\cline { 2 - 5 } Treatment & $\begin{array}{c}\text { Shoot Growth } \\
\text { Period }\end{array}$ & Flowering Period & $\begin{array}{c}\text { Berry Growth } \\
\text { Period }\end{array}$ & $\begin{array}{c}\text { Berry Mature } \\
\text { Period }\end{array}$ \\
\hline W1F1 & $0.602 \pm 0.02 \mathrm{i}$ & $0.621 \pm 0.02 \mathrm{~h}$ & $0.653 \pm 0.01 \mathrm{f}$ & $0.638 \pm 0.02 \mathrm{f}$ \\
W1F2 & $0.704 \pm 0.01 \mathrm{fg}$ & $0.732 \pm 0.01 \mathrm{fg}$ & $0.761 \pm 0.02 \mathrm{~cd}$ & $0.740 \pm 0.01 \mathrm{~cd}$ \\
W1F3 & $0.730 \pm 0.01 \mathrm{ef}$ & $0.763 \pm 0.01 \mathrm{def}$ & $0.798 \pm 0.02 \mathrm{bc}$ & $0.769 \pm 0.02 \mathrm{bc}$ \\
W2F1 & $0.637 \pm 0.02 \mathrm{hi}$ & $0.656 \pm 0.02 \mathrm{~h}$ & $0.690 \pm 0.03 \mathrm{ef}$ & $0.670 \pm 0.01 \mathrm{ef}$ \\
W2F2 & $0.736 \pm 0.01 \mathrm{def}$ & $0.777 \pm 0.01 \mathrm{cde}$ & $0.805 \pm 0.01 \mathrm{abc}$ & $0.776 \pm 0.02 \mathrm{bc}$ \\
W2F3 & $0.756 \pm 0.02 \mathrm{cde}$ & $0.793 \pm 0.02 \mathrm{bcd}$ & $0.821 \pm 0.03 \mathrm{ab}$ & $0.808 \pm 0.02 \mathrm{ab}$ \\
W3F1 & $0.674 \pm 0.02 \mathrm{gh}$ & $0.707 \pm 0.02 \mathrm{~g}$ & $0.725 \pm 0.01 \mathrm{de}$ & $0.710 \pm 0.02 \mathrm{de}$ \\
W3F2 & $0.773 \pm 0.01 \mathrm{bcd}$ & $0.804 \pm 0.01 \mathrm{abc}$ & $0.825 \pm 0.02 \mathrm{ab}$ & $0.813 \pm 0.01 \mathrm{ab}$ \\
W3F3 & $0.785 \pm 0.02 \mathrm{abc}$ & $0.820 \pm 0.02 \mathrm{ab}$ & $0.837 \pm 0.01 \mathrm{ab}$ & $0.824 \pm 0.03 \mathrm{a}$ \\
W4F1 & $0.712 \pm 0.01 \mathrm{fg}$ & $0.753 \pm 0.01 \mathrm{ef}$ & $0.771 \pm 0.03 \mathrm{c}$ & $0.758 \pm 0.01 \mathrm{c}$ \\
W4F2 & $0.807 \pm 0.02 \mathrm{ab}$ & $0.825 \pm 0.02 \mathrm{ab}$ & $0.841 \pm 0.02 \mathrm{ab}$ & $0.830 \pm 0.04 \mathrm{a}$ \\
W4F3 & $0.815 \pm 0.01 \mathrm{a}$ & $0.832 \pm 0.01 \mathrm{a}$ & $0.849 \pm 0.01 \mathrm{a}$ & $0.841 \pm 0.02 \mathrm{a}$ \\
\hline & Two-factor analysis of variance $(F$ value analysis $)$ & \\
\hline W & $3.349 *$ & 3.085 & 2.131 & 2.866 \\
F & $17.639 * *$ & $17.570 * *$ & $21.946^{* *}$ & $18.100 * *$ \\
W $\times$ F & $30.097^{* *}$ & $34.131^{* *}$ & $20.204 * *$ & $23.204{ }^{* *}$ \\
\hline
\end{tabular}

In summary, reasonable water and fertilizer use can increase the activity of Ribulose-1,5-bisphosphate (RUBP) carboxylase in grape leaves and then increase the $F_{v} / F_{m}$, so as to increase the accumulation of photosynthetic products in crops.

\subsubsection{Effects of Water and Fertilizer Application on $q^{P}$ of Drip Irrigation Grape Leaves}

The change law and variance analysis of the photochemical quenching coefficient $\left(q^{P}\right)$ are shown in Table 7. The effects of water and fertilizer interaction, fertilization single factor on the $q^{P}$ of grape leaves under drip irrigation at different growth stages, reached a very significant level $(p<0.01)$ and the single factor of fertilization reached a significant level $(p<0.05)$.

The value $q^{P}$ refers to the fluorescence quenching caused by the excitation energy being captured by the open reaction center and converted into chemical energy, reflecting the redox state of PSII stability of the original electron acceptor QA and the openness of the PSII reaction center, further reflecting the crop's photosynthetic efficiency and utilization of light energy [30]. It can be seen from Table 7 that the $q^{P}$ of drip irrigation grape leaves reached the highest level in the berry growth period and the average value of water and fertilizer treatment was 0.760 , which was the lowest level in the 
new shoot growth period. The average value of each water and fertilizer treatment was 0.467 , which was promoted with the growth period, with the overall trend increasing and then decreasing. Under different fertility treatments, the $q^{P}$ of drip-irrigated grape leaves, under different fertility treatments, showed that, under the same fertilization conditions, the $q^{P}$ of grape leaves increased first and then decreased with the increase of irrigation amount. Under the same irrigation condition, the $q^{P}$ of grape leaves increased first and then decreased with the increase of fertilization amount. Under the condition of water and fertilizer interaction, the maximum value of $q^{P}$ in grape leaves appeared in the W3F2 treatment, and the minimum appeared in the W1F3 treatment.

Table 7. Effects of water and fertilizer application on the $q^{P}$ of drip irrigation grape leaves.

\begin{tabular}{ccccc}
\hline Treatment & \multicolumn{4}{c}{$q^{P}$} \\
\cline { 2 - 5 } & $\begin{array}{c}\text { Shoot Growth } \\
\text { Period }\end{array}$ & Flowering Period & $\begin{array}{c}\text { Berry Growth } \\
\text { Period }\end{array}$ & $\begin{array}{c}\text { Berry Mature } \\
\text { Period }\end{array}$ \\
\hline W1F1 & $0.378 \pm 0.02 \mathrm{~g}$ & $0.501 \pm 0.01 \mathrm{fg}$ & $0.659 \pm 0.01 \mathrm{~g}$ & $0.629 \pm 0.01 \mathrm{f}$ \\
W1F2 & $0.423 \pm 0.03 \mathrm{fg}$ & $0.536 \pm 0.01 \mathrm{ef}$ & $0.690 \pm 0.02 \mathrm{fg}$ & $0.673 \pm 0.03 \mathrm{ef}$ \\
W1F3 & $0.301 \pm 0.01 \mathrm{~h}$ & $0.442 \pm 0.02 \mathrm{~g}$ & $0.603 \pm 0.03 \mathrm{~h}$ & $0.557 \pm 0.02 \mathrm{~g}$ \\
W2F1 & $0.453 \pm 0.03 \mathrm{def}$ & $0.591 \pm 0.03 \mathrm{de}$ & $0.762 \pm 0.02 \mathrm{de}$ & $0.728 \pm 0.01 \mathrm{~cd}$ \\
W2F2 & $0.484 \pm 0.01 \mathrm{~cd}$ & $0.632 \pm 0.02 \mathrm{~cd}$ & $0.805 \pm 0.01 \mathrm{~cd}$ & $0.767 \pm 0.02 \mathrm{c}$ \\
W2F3 & $0.393 \pm 0.01 \mathrm{~g}$ & $0.524 \pm 0.03 \mathrm{f}$ & $0.694 \pm 0.02 \mathrm{fg}$ & $0.662 \pm 0.02 \mathrm{ef}$ \\
W3F1 & $0.568 \pm 0.01 \mathrm{~b}$ & $0.715 \pm 0.02 \mathrm{ab}$ & $0.863 \pm 0.02 \mathrm{ab}$ & $0.829 \pm 0.03 \mathrm{ab}$ \\
W3F2 & $0.618 \pm 0.02 \mathrm{a}$ & $0.773 \pm 0.03 \mathrm{a}$ & $0.907 \pm 0.04 \mathrm{a}$ & $0.873 \pm 0.04 \mathrm{a}$ \\
W3F3 & $0.478 \pm 0.03 \mathrm{cde}$ & $0.623 \pm 0.04 \mathrm{~d}$ & $0.782 \pm 0.03 \mathrm{~d}$ & $0.756 \pm 0.01 \mathrm{c}$ \\
W4F1 & $0.514 \pm 0.04 \mathrm{c}$ & $0.646 \pm 0.02 \mathrm{~cd}$ & $0.793 \pm 0.02 \mathrm{~cd}$ & $0.766 \pm 0.01 \mathrm{c}$ \\
W4F2 & $0.566 \pm 0.01 \mathrm{~b}$ & $0.688 \pm 0.05 \mathrm{bc}$ & $0.833 \pm 0.01 \mathrm{bc}$ & $0.814 \pm 0.02 \mathrm{~b}$ \\
W4F3 & $0.429 \pm 0.02 \mathrm{efg}$ & $0.558 \pm 0.01 \mathrm{ef}$ & $0.724 \pm 0.01 \mathrm{ef}$ & $0.695 \pm 0.01 \mathrm{de}$ \\
\hline & Two-factor analysis of variance $(F$ value analysis $)$ & \\
\hline W & $11.286^{* *}$ & $13.267^{* *}$ & $15.358^{* *}$ & $14.397^{* *}$ \\
F & $5.195^{*}$ & $4.118^{*}$ & $3.834^{*}$ & $4.235 *$ \\
W $\times$ F & $32.874^{* *}$ & $23.906^{* *}$ & $34.234^{* *}$ & $37.291 * *$ \\
\hline
\end{tabular}

In summary, a reasonable amount of water and fertilizer can increase the openness and photochemical activity of the PSII reaction center, reduce the degree of photoinhibition of the crop, and thus achieve the purpose of improving the photosynthetic capacity of the crop.

\subsubsection{Effects of Water and Fertilizer Application on ФPSII of Drip Irrigation Grape Leaves}

The effects of different water and fertilizer treatments on PSII actual photochemical quantum efficiency (ФPSII) of grape leaves in drip-irrigated grape leaves at different growth stages are shown in Table 8. The effects of water and fertilizer interaction, fertilization single factor on ФPSII of grape leaves under drip irrigation at different growth stages, reached a very significant level $(p<0.01)$ and the single factor of fertilization reached a significant level $(p<0.05)$.

The value $\Phi P S I I$ refers to the quantum efficiency of the actual electron transfer, reflecting the transmission of PSII and PSI. It can be seen from Table 8 that the $\Phi$ PSII of the drip irrigation grape leaves reached the highest level in the berry growth period and the average value of each water and fertilizer treatment was 0.584 , which was the lowest level in the new shoot growth period. The average value of each water and fertilizer treatment was 0.338 , which was promoted with the growth period, with the overall trend increasing and then decreasing. Under different fertility treatments, the ФPSII of drip-irrigated grape leaves showed that, under the same fertilization conditions, the $\Phi P S I I$ of grape leaves increased first and then decreased with the increase of irrigation amount. Under the same irrigation condition, the $\Phi P S I I$ of grape leaves increased first and then decreased with the increase of the fertilization amount. Under the condition of water and fertilizer interaction, the maximum value of the $\Phi P S I I$ of grape leaves appeared in the W3F2 treatment and the minimum appeared in the W1F1 treatment. 
In summary, a reasonable amount of water and fertilizer can improve the antioxidant capacity of crop leaves, slow down the oxidation rate of membrane lipids, enhance the photosynthetic electron capacity, and thus achieve the purpose of improving crop photosynthetic capacity.

Table 8. Effects of water and fertilizer application on the $\Phi P S I I$ of drip irrigation grape leaves.

\begin{tabular}{|c|c|c|c|c|}
\hline \multirow[b]{2}{*}{ Treatment } & \multicolumn{4}{|c|}{ ФPSII } \\
\hline & $\begin{array}{l}\text { Shoot Growth } \\
\text { Period }\end{array}$ & Flowering Period & $\begin{array}{l}\text { Berry Growth } \\
\text { Period }\end{array}$ & $\begin{array}{c}\text { Berry Mature } \\
\text { Period }\end{array}$ \\
\hline W1F1 & $0.218 \pm 0.03 d$ & $0.311 \pm 0.01 \mathrm{~h}$ & $0.425 \pm 0.01 \mathrm{~h}$ & $0.401 \pm 0.02 \mathrm{~g}$ \\
\hline W1F2 & $0.298 \pm 0.02 c$ & $0.392 \pm 0.01 \mathrm{efg}$ & $0.525 \pm 0.03 g$ & $0.498 \pm 0.03 \mathrm{e}$ \\
\hline W1F3 & $0.220 \pm 0.01 \mathrm{~d}$ & $0.337 \pm 0.02 \mathrm{gh}$ & $0.454 \pm 0.01 \mathrm{gh}$ & $0.428 \pm 0.01 \mathrm{fg}$ \\
\hline W2F1 & $0.289 \pm 0.03 c$ & $0.388 \pm 0.02 \mathrm{fg}$ & $0.501 \pm 0.01 \mathrm{~g}$ & $0.478 \pm 0.01 \mathrm{ef}$ \\
\hline W2F2 & $0.356 \pm 0.01 b$ & $0.491 \pm 0.02 c^{\circ}$ & $0.648 \pm 0.03 \mathrm{bcd}$ & $0.595 \pm 0.03 c d$ \\
\hline W2F3 & $0.297 \pm 0.01 c$ & $0.416 \pm 0.04 \mathrm{def}$ & $0.564 \pm 0.01 \mathrm{f}$ & $0.535 \pm 0.03 \mathrm{de}$ \\
\hline W3F1 & $0.368 \pm 0.03 b$ & $0.506 \pm 0.02 b c$ & $0.601 \pm 0.01 \mathrm{~cd}$ & $0.579 \pm 0.02 \mathrm{~cd}$ \\
\hline W3F2 & $0.478 \pm 0.02 \mathrm{a}$ & $0.621 \pm 0.04 a$ & $0.748 \pm 0.04 a$ & $0.710 \pm 0.04 a$ \\
\hline W3F3 & $0.375 \pm 0.02 b$ & $0.511 \pm 0.03 \mathrm{bc}$ & $0.645 \pm 0.01 b c$ & $0.623 \pm 0.03 b c$ \\
\hline W4F1 & $0.346 \pm 0.03 b$ & $0.456 \pm 0.02$ cde & $0.575 \pm 0.01 \mathrm{ef}$ & $0.566 \pm 0.01 \mathrm{~cd}$ \\
\hline W4F2 & $0.457 \pm 0.01 \mathrm{a}$ & $0.568 \pm 0.05 \mathrm{ab}$ & $0.701 \pm 0.03 b$ & $0.676 \pm 0.04 \mathrm{ab}$ \\
\hline W4F3 & $0.350 \pm 0.01 b$ & $0.464 \pm 0.01 \mathrm{~cd}$ & $0.621 \pm 0.01 \mathrm{de}$ & $0.584 \pm 0.02 \mathrm{~cd}$ \\
\hline \multicolumn{5}{|c|}{ Two-factor analysis of variance ( $F$ value analysis) } \\
\hline $\mathrm{W}$ & $13.030^{* *}$ & $14.647^{* *}$ & $16.226^{* *}$ & $14.321 * *$ \\
\hline $\mathrm{F}$ & $4.332 *$ & $3.530 *$ & $3.613 *$ & $3.893 *$ \\
\hline $\mathrm{W} \times \mathrm{F}$ & $31.988^{* *}$ & $20.414^{* *}$ & $46.168^{* *}$ & $26.511^{* *}$ \\
\hline
\end{tabular}

3.3. Effect of Water and Fertilizer Dosage on Grape Yield, Water Use Efficiency, and the Quality of Drip Irrigation

The effects of different water and fertilizer treatments on the yield, water use efficiency, and the quality of drip irrigation during different growth periods are shown in Table 9. The effects of water and fertilizer interaction on the yield, water use efficiency, and the quality of drip irrigation, in different growth stages, reached extremely significant levels $(p<0.01)$.

It is observable from Table 9 that the yield of drip irrigation grape is between $20317 \mathrm{~kg} \mathrm{ha}^{-1}$ and $26364 \mathrm{~kg} \mathrm{ha}^{-1}$. Under the same fertilization condition, the yield of F1 fertilization treatment increased with the increase of irrigation amount. The yield of F2 and F3 fertilization treatment increased first and then decreased with the increase of irrigation amount. Under the same irrigation conditions, the yield of W1 and W2 irrigation treatment increased with the increase of fertilization amount. W4 irrigation treatment yield increased first and then decreased with the increase of fertilizer application. The maximum yield was obtained in W3F2 treatment. The irrigation water use efficiency and fertilizer partial productivity reached the maximum at W1F3 $\left(3.54 \mathrm{~kg} \cdot \mathrm{m}^{-3}\right)$ and W4F1 $(54.78$ $\mathrm{kg} \cdot \mathrm{kg}^{-1}$ ), respectively, and did not reach optimal in W3F2. The soluble solids ranged from $19.56 \%$ to $22.45 \%$, which was the largest in the W3F2 treatment. Titratable acid ranged from $0.420 \%$ to $0.541 \%$, of which the maximum value was obtained in the W4F2 treatment and there was no significant difference between the W4F2 treatment and the W3F2 treatment $(p>0.05)$. Vitamin C was between 7.37 $\mathrm{mg} \cdot 100 \mathrm{~g}^{-1}-8.52 \mathrm{mg} \cdot 100 \mathrm{~g}^{-1}$, of which the maximum value is obtained in the W4F3 treatment. There was no significant difference between the W4F3 treatment and the W3F2 treatment $(p>0.05)$. The yield increase effect reflected the increase of the yield of different water and fertilizer treatments, compared with the W1F1 treatment. The yield increase effect of the W3F2 treatment reached a maximum of $29.76 \%$, most obviously, this is consistent with the results of the production indicators.

In summary, the W3F2 treatment has the most obvious effect on improving grape yield and grape quality, indicating that reasonable water and fertilizer use can improve crop yield and quality indicators and achieve the purpose of improving quality and efficiency. 
Table 9. Effect of water and fertilizer dosage on grape yield, water use efficiency, and the quality of drip irrigation.

\begin{tabular}{|c|c|c|c|c|c|c|c|}
\hline Treatment & Yield $\left(\mathrm{kg} \mathrm{ha}^{-1}\right)$ & iWUE $\left(\mathrm{kg} \cdot \mathrm{m}^{-3}\right)$ & $P F P\left(\mathrm{~kg} \cdot \mathrm{kg}^{-1}\right)$ & $E i(\%)$ & Soluble Solid (\%) & Titratable Acid (\%) & Vitamin $C\left(\mathrm{mg} \cdot 100 \mathrm{~g}^{-1}\right.$ \\
\hline W1F1 & $20317 \pm 287 g$ & $3.39 \pm 0.04 b c$ & $45.15 \pm 0.63 c$ & - & $19.56 \pm 0.20 h$ & $0.420 \pm 0.02 \mathrm{e}$ & $7.37 \pm 0.06 f$ \\
\hline W1F2 & $20676 \pm 376 \mathrm{fg}$ & $3.45 \pm 0.06 \mathrm{ab}$ & $27.57 \pm 0.50 \mathrm{~g}$ & 1.77 & $21.31 \pm 0.30 \mathrm{~cd}$ & $0.445 \pm 0.01 \mathrm{de}$ & $7.92 \pm 0.05 \mathrm{~d}$ \\
\hline W1F3 & $21266 \pm 79 f$ & $3.54 \pm 0.01 \mathrm{a}$ & $20.25 \pm 0.07 j$ & 4.67 & $20.94 \pm 0.16 \mathrm{de}$ & $0.495 \pm 0.01 b c$ & $8.34 \pm 0.07 \mathrm{~b}$ \\
\hline W2F1 & $22562 \pm 183 e$ & $3.34 \pm 0.02 c$ & $50.14 \pm 0.40 b$ & 11.05 & $19.83 \pm 0.18 \mathrm{gh}$ & $0.445 \pm 0.02 \mathrm{de}$ & $7.69 \pm 0.01 \mathrm{e}$ \\
\hline $\mathrm{W} 2 \mathrm{~F} 2$ & $22828 \pm 534 \mathrm{e}$ & $3.38 \pm 0.07 \mathrm{bc}$ & $30.44 \pm 0.71 f$ & 12.36 & $21.72 \pm 0.20 \mathrm{bc}$ & $0.502 \pm 0.01 b c$ & $8.06 \pm 0.01 c$ \\
\hline W2F3 & $23725 \pm 287 d$ & $3.51 \pm 0.04 a$ & $22.60 \pm 0.27 \mathrm{i}$ & 16.77 & $21.29 \pm 0.28 \mathrm{~cd}$ & $0.506 \pm 0.01 \mathrm{ab}$ & $8.32 \pm 0.03 b$ \\
\hline W3F1 & $24356 \pm 175 c d$ & $3.25 \pm 0.02 \mathrm{~d}$ & $54.12 \pm 0.38 \mathrm{a}$ & 19.88 & $20.08 \pm 0.27 \mathrm{fgh}$ & $0.467 \pm 0.01 \mathrm{~cd}$ & $7.97 \pm 0.02 \mathrm{~cd}$ \\
\hline W3F2 & $26364 \pm 397 a$ & $3.52 \pm 0.05 a$ & $25.11 \pm 0.37 \mathrm{~h}$ & 29.76 & $22.45 \pm 0.42 \mathrm{a}$ & $0.541 \pm 0.01 \mathrm{a}$ & $8.45 \pm 0.10 \mathrm{ab}$ \\
\hline W3F3 & $25320 \pm 190 b$ & $3.38 \pm 0.02 b c$ & $33.76 \pm 0.25 \mathrm{e}$ & 24.62 & $20.92 \pm 0.24 \mathrm{de}$ & $0.492 \pm 0.02 b c$ & $8.49 \pm 0.02 a$ \\
\hline W4F1 & $24649 \pm 272 b c$ & $2.99 \pm 0.03 e$ & $54.78 \pm 0.60 a$ & 21.32 & $20.44 \pm 0.17 \mathrm{ef}$ & $0.501 \pm 0.03 b c$ & $7.71 \pm 0.08 b$ \\
\hline W4F2 & $26077 \pm 313 a$ & $3.16 \pm 0.03 \mathrm{~d}$ & $34.77 \pm 0.41 \mathrm{~d}$ & 28.35 & $22.07 \pm 0.28 \mathrm{ab}$ & $0.541 \pm 0.02 \mathrm{a}$ & $8.33 \pm 0.07 \mathrm{~b}$ \\
\hline W4F3 & $24715 \pm 162 b c$ & $3.00 \pm 0.01 \mathrm{e}$ & $23.54 \pm 0.15 \mathrm{i}$ & 21.65 & $20.26 \pm 0.25 f g$ & $0.522 \pm 0.02 \mathrm{ab}$ & $8.52 \pm 0.10 \mathrm{a}$ \\
\hline \multicolumn{8}{|c|}{ Two-factor analysis of variance ( $F$ value analysis) } \\
\hline $\mathrm{W}$ & $54.931 * *$ & $22.151 * *$ & 0.366 & / & 0.343 & $4.706^{*}$ & 1.71 \\
\hline $\mathrm{F}$ & 0.553 & 1.373 & $166.542 * *$ & / & $36.909 * *$ & $5.300 *$ & $28.686^{* *}$ \\
\hline $\mathrm{W} \times \mathrm{F}$ & $95.18^{* *}$ & $39.393 * *$ & $1646.636^{* *}$ & / & $24.912 * *$ & $11.316^{* *}$ & $74.356^{* *}$ \\
\hline
\end{tabular}


3.4. Comprehensive Evaluation of Suitable Amount of Water and Fertilizer for Drip Irrigation Grapes in Extreme Arid Areas

3.4.1. Evaluation of Suitable Amounts of Water and Fertilizer for Drip Irrigation Grapes in Extreme Arid Area Based on Principal Component Analysis

In the evaluation process of grape drip irrigation water and fertilizer treatment, it is not convincing to evaluate the rationality of water and fertilizer treatment only through the single response indicator of crops. Therefore, based on principal component analysis, the net photosynthetic rate $\left(P_{n}\right)$, the original photochemical maximum yield $\left(F_{v} / F_{m}\right)$, yield, irrigation water use efficiency, fertilizer partial productivity, soluble solids, titratable acid, and vitamin $C$ were comprehensively quantified to evaluate the optimal water and fertilizer treatment, of which $P_{n}$ and $F_{v} / F_{m}$, the analytical data for the indicators, were selected from the growth stage of berries with vigorous physiological activities, as shown in Table 10.

Table 10. Response value of each drip irrigation grape with different water and fertilizer treatment.

\begin{tabular}{ccccccccc}
\hline Treatment & $\boldsymbol{P}_{\boldsymbol{n}}$ & $\boldsymbol{F}_{\boldsymbol{v}} / \boldsymbol{F}_{\boldsymbol{m}}$ & Yield & $\boldsymbol{i W U E}$ & $\boldsymbol{F P P}$ & Soluble Solid & Titratable Acid & Vitamin C \\
\hline W1F1 & 25.00 & 0.653 & 20317 & 3.386 & 45.149 & 19.56 & 0.420 & 7.37 \\
W1F2 & 25.80 & 0.761 & 20676 & 3.446 & 27.568 & 21.31 & 0.445 & 7.92 \\
W1F3 & 25.23 & 0.798 & 21266 & 3.544 & 20.253 & 20.94 & 0.495 & 8.34 \\
W2F1 & 27.93 & 0.690 & 22562 & 3.343 & 50.138 & 19.83 & 0.445 & 7.69 \\
W2F2 & 30.55 & 0.805 & 22828 & 3.382 & 30.437 & 21.72 & 0.502 & 8.06 \\
W2F3 & 28.09 & 0.821 & 23725 & 3.515 & 22.595 & 21.29 & 0.506 & 8.32 \\
W3F1 & 30.98 & 0.725 & 24356 & 3.247 & 54.124 & 20.08 & 0.467 & 7.97 \\
W3F2 & 33.27 & 0.825 & 26364 & 3.376 & 33.760 & 22.45 & 0.541 & 8.45 \\
W3F3 & 31.98 & 0.837 & 25320 & 3.515 & 25.109 & 20.92 & 0.492 & 8.49 \\
W4F1 & 32.00 & 0.771 & 24649 & 2.988 & 54.776 & 20.44 & 0.501 & 7.71 \\
W4F2 & 33.45 & 0.841 & 26077 & 3.161 & 34.769 & 22.07 & 0.541 & 8.33 \\
W4F3 & 32.50 & 0.849 & 24715 & 2.996 & 23.538 & 20.26 & 0.522 & 8.52 \\
\hline
\end{tabular}

The comprehensive evaluation analysis calculates the comprehensive evaluation value according to the MATLAB program, given by Equation (7) in combination with Equations (8) and (9).

The comprehensive evaluation of different water and fertilizer treatments based on the response indicators of drip irrigation grapes is shown in Table 11. It is observable from the above that W3F2 is integrated and its evaluation value was the highest, followed by the W4F2 and W3F3 treatments, indicating that the comprehensive response index of the W3F2 treatment drip irrigation grape was the best. The W4F2 and W3F3 treatments had higher comprehensive response indicators among all the fertilization treatments. The comprehensive evaluation value of each treatment under the F1 fertilization level was low and the effect was the worst. It is indicated that the reasonable amount of water and fertilizer can make the comprehensive evaluation of each response index of drip irrigation grape reach the best level, which is conducive to crop growth and development and can achieve the purpose of improving yield and quality.

Table 11. Comprehensive evaluation of different water and fertilizer treatments based on the response indicators of drip irrigation grapes.

\begin{tabular}{ccccc}
\hline Treatment & $Z_{\mathbf{1}}$ & $Z_{\mathbf{2}}$ & $\boldsymbol{Z}$ & Rank \\
\hline W1F1 & -4.34 & -0.01 & -2.56 & 12 \\
W1F2 & -1.59 & 1.68 & -0.48 & 8 \\
W1F3 & -0.30 & 2.40 & 0.48 & 7 \\
W2F1 & -2.67 & -0.80 & -1.79 & 11 \\
W2F2 & 0.59 & 0.59 & 0.51 & 6 \\
W2F3 & 0.84 & 1.56 & 0.92 & 4 \\
W3F1 & -1.13 & -1.67 & -1.12 & 10 \\
W3F2 & 2.78 & -0.10 & 1.61 & 1 \\
W3F3 & 1.52 & 0.78 & 1.11 & 3 \\
W4F1 & -0.30 & -2.68 & -0.91 & 9 \\
W4F2 & 2.66 & -0.90 & 1.32 & 2 \\
W4F3 & 1.94 & -0.86 & 0.91 & 5 \\
\hline
\end{tabular}


3.4.2. Comprehensive Evaluation of Suitable Amount of Water and Fertilizer for Drip Irrigation Grape in an Extreme Arid Area, Based on Grey Correlation Analysis

The gray correlation analysis method was used to comprehensively evaluate the suitable amount of grape drip irrigation water and fertilizer and the significance and purpose were consistent with the principal component analysis. The aim was to compare the net photosynthetic rate $\left(P_{n}\right)$ of the drip irrigation grape response index and the maximum photochemical yield $\left(F_{v} / F_{m}\right)$. Comprehensively, quantitative analyses of yield, irrigation water use efficiency, fertilizer partial productivity, soluble solids, titratable acid, and vitamin C were carried out to evaluate the optimal water and fertilizer treatment.

The response index data of drip irrigation grapes, under different water and fertilizer treatments, were used as comparison series. Maximum values of response indexes, under different water and fertilizer treatments, were used as reference series. The analysis data of $P_{n}$ and $F_{v} / F_{m}$ were selected from the growth period of berries with vigorous physiological activities, as shown in Table 12.

Table 12. Comparison series and reference series of response indexes of drip irrigation grapes with different water and fertilizer treatments.

\begin{tabular}{|c|c|c|c|c|c|c|c|c|c|}
\hline Treatment & Sequence & $P_{n}$ & $F_{v} / F_{m}$ & Yield & iWUE & $P F P$ & Soluble Solid & Titratable Acid & Vitamin C \\
\hline $\begin{array}{l}\text { Reference } \\
\text { sequence }\end{array}$ & $\mathrm{x} 0$ & 33.45 & 0.849 & 26364 & 3.544 & 54.776 & 22.45 & 0.541 & 8.52 \\
\hline W1F1 & $x 1$ & 25.00 & 0.653 & 20317 & 3.386 & 45.149 & 19.56 & 0.420 & 7.37 \\
\hline W1F2 & $\mathrm{x} 2$ & 25.80 & 0.761 & 20676 & 3.446 & 27.568 & 21.31 & 0.445 & 7.92 \\
\hline W1F3 & $x 3$ & 25.23 & 0.798 & 21266 & 3.544 & 20.253 & 20.94 & 0.495 & 8.34 \\
\hline W2F1 & $x 4$ & 27.93 & 0.690 & 22562 & 3.343 & 50.138 & 19.83 & 0.445 & 7.69 \\
\hline W2F2 & $x 5$ & 30.55 & 0.805 & 22828 & 3.382 & 30.437 & 21.72 & 0.502 & 8.06 \\
\hline W2F3 & $x 6$ & 28.09 & 0.821 & 23725 & 3.515 & 22.595 & 21.29 & 0.506 & 8.32 \\
\hline W3F1 & $x 7$ & 30.98 & 0.725 & 24356 & 3.247 & 54.124 & 20.08 & 0.467 & 7.97 \\
\hline W3F2 & $x 8$ & 33.27 & 0.825 & 26364 & 3.376 & 33.760 & 22.45 & 0.541 & 8.45 \\
\hline W3F3 & $\mathrm{x} 9$ & 31.98 & 0.837 & 25320 & 3.515 & 25.109 & 20.92 & 0.492 & 8.49 \\
\hline W4F1 & $\mathrm{x} 10$ & 32.00 & 0.771 & 24649 & 2.988 & 54.776 & 20.44 & 0.501 & 7.71 \\
\hline W4F2 & x11 & 33.45 & 0.841 & 26077 & 3.161 & 34.769 & 22.07 & 0.541 & 8.33 \\
\hline W4F3 & x12 & 32.50 & 0.849 & 24715 & 2.996 & 23.538 & 20.26 & 0.522 & 8.52 \\
\hline
\end{tabular}

The grey correlation analysis calculates the relevance value according to the MATLAB program, given by Equation (10). The comprehensive evaluation of different water and fertilizer treatments, based on the response indicators of drip irrigation grapes, is shown in Table 13. It can be seen from the above that the correlation of W3F2 is the highest, followed by W3F3 and W4F2. In the fertilization treatment, the correlation degree of each treatment under the F1 fertilization level was generally low and the effect was poor. The analysis results are basically consistent with the conclusions obtained by principal component analysis, which further demonstrates that the reasonable comprehensive response index of crops under water and fertilizer treatment can achieve the purpose of improving quality and efficiency.

Table 13. Comprehensive evaluation of different water and fertilizer treatments based on the response indicators of drip irrigation grapes.

\begin{tabular}{ccc}
\hline Treatment & Correlation Degree & Rank \\
\hline W1F1 & 0.724 & 12 \\
W1F2 & 0.771 & 9 \\
W1F3 & 0.779 & 8 \\
W2F1 & 0.738 & 10 \\
W2F2 & 0.785 & 7 \\
W2F3 & 0.799 & 5 \\
W3F1 & 0.797 & 6 \\
W3F2 & 0.829 & 1 \\
W3F3 & 0.824 & 2 \\
W4F1 & 0.736 & 11 \\
W4F2 & 0.822 & 3 \\
W4F3 & 0.811 & 4 \\
\hline
\end{tabular}


3.4.3. Comprehensive Evaluation of suitable Amount of Water and Fertilizer for Drip Irrigation Grapes in an Extreme Arid Area, Based on Multiple Regression Analysis

In order to understand the dynamic and continuous changes of the response indexes of drip irrigation grapes in the setting range of water and fertilizer use, comprehensively quantitative evaluation of the suitable amount of water and fertilizer for drip irrigation in extremely arid areas, the water and fertilizer dosage, were treated as independent variables, the values $P_{n}, F_{v} / F_{m}$, yield, irrigation water use efficiency, fertilizer partial productivity, soluble solids, titratable acid, and vitamin $\mathrm{C}$ were regarded as output variables and regression analysis was adopted to construct a regression equation (see Table 14). It can be seen from Table 14 that the effect of water and fertilizer dosage on each output variable reached a significant level $(p<0.05)$ and the determination coefficient was more than 0.800 .

Table 14. Regression relationship between water and fertilizer use and response indicators of drip irrigation grapes.

\begin{tabular}{ccccc}
\hline Output Variables $Y$ & Regression Equation & $\boldsymbol{R}^{\mathbf{2}}$ & Significant \\
\hline$P_{n}$ & $Y_{1}=-1.260 \times 10^{-4} W^{2}-1.741 \times 10^{-5} F^{2}+3.744 \times 10^{-6} W F+0.210 W+0.024 F-62.697$ & 0.973 & $<0.01$ \\
$F_{v} / F_{m}$ & $Y_{2}=-4.994 \times 10^{-7} W^{2}-4.510 \times 10^{-7} F^{2}-6.928 \times 10^{-7} W F+0.002 W+0.001 F-0.518$ & 0.967 & $<0.01$ \\
Yield & $Y_{3}=-0.115 W^{2}-0.001 F^{2}-0.003 W F+186.552 W+5.659 F-51085.576$ & 0.891 & $<0.01$ \\
$i W U E$ & $Y_{4}=-1.322 \times 10^{-5} W^{2}-7.064 \times 10^{-7} F^{2}-9.287 \times 10^{-7} W F+0.018 W+0.002 F-3.073$ & 0.831 & $<0.05$ \\
$F P P$ & $Y_{5}=-1.571 \times 10^{-4} W^{2}+9.682 \times 10^{-5} F^{2}-2.351 \times 10^{-5} W F+0.273 W-0.172 F+3.257$ & 0.912 & $<0.01$ \\
Soluble solid & $Y_{6}=-2.037 \times 10^{-5} W^{2}-1.544 \times 10^{-5} F^{2}-1.151 \times 10^{-5} W F+0.040 W+0.033 F-5.660$ & 0.891 & $<0.01$ \\
Titratable acid & $Y_{7}=-3.778 \times 10^{-7} W^{2}-2.090 \times 10^{-7} F^{2}-3.433 \times 10^{-7} W F+0.001 W+6.242 \times 10^{-4} F-0.158$ & 0.825 & $<0.05$ & $<.0 .01$ \\
Vitamin C & $Y_{8}=-1.117 \times 10^{-5} W^{2}-1.538 \times 10^{-6} F^{2}-1.616 \times 10^{-6} W F+0.019 W+0.005 F-1.313$ & 0.897 & $<0.01$ \\
\hline
\end{tabular}

Under the condition of drip irrigation, the irrigation amount of W1 and W4 treatments were respectively the upper and lower limits of watering and the fertilization amounts of F1 and F3 treatment were the upper and lower limits of fertilization, respectively. MATLAB is used to solve the maximum value of each regression equation in Table 14 and the corresponding water and fertilizer dosage.

Table 15 shows that under the same water and fertilizer dosage, the response index of drip-irrigated grape did not reach the maximum value, among which the $P_{n}, F_{v} / F_{m}$, yield, soluble solids, titratable acid, and vitamin $C$ index were relatively close to the irrigation and fertilization area, while $i W U E$ and PFP were similar to other indicators in the irrigation and fertilization area. Since the area is far away, two indices of $i W U E$ and PFP will not be considered in the following comprehensive evaluation.

Table 15. The maximum response index of drip irrigation grapes and the corresponding water and fertilizer dosages.

\begin{tabular}{cccc}
\hline Output Variable & Maximum & Irrigation Amount/ (mm) & ${\text { Fertilization Amount/ }\left(\mathbf{k g ~ h a}^{-\mathbf{1}}\right)}$ \\
\hline$P_{n} /\left(\mu \mathrm{mol} \cdot \mathrm{m}^{-2} \cdot \mathrm{s}^{-1}\right)$ & 35.331 & 825.000 & 777.967 \\
$\mathrm{Fv} / \mathrm{Fm}$ & 0.895 & 825.000 & 474.998 \\
Yield $/\left(\mathrm{kg} \mathrm{ha}^{-1}\right)$ & 26876 & 797.400 & 1050.000 \\
$i W U E /\left(\mathrm{kg} \cdot \mathrm{m}^{-3}\right)$ & 3.732 & 645.979 & 990.987 \\
$P F P /\left(\mathrm{kg} \cdot \mathrm{kg}^{-1}\right)$ & 55.035 & 825.000 & 450.000 \\
Soluble solid $/(\%)$ & 22.498 & 759.926 & 785.421 \\
Titratable acid $/(\%)$ & 0.549 & 825.000 & 815.736 \\
Vitamin C/ $\left(\mathrm{mg} \cdot 100 \mathrm{~g}^{-1}\right)$ & 8.942 & 774.500 & 1050.000 \\
\hline
\end{tabular}

As a consequence of the $P_{n}, F_{v} / F_{m}$, yield, soluble solids, titratable acid, and vitamin C could not reach their maximum values under the same water and fertilizer application and each response indicator has different dimensions and cannot be directly evaluated comprehensively. Therefore, before the comprehensive evaluation, the linear normalization method is used to dimensionalize all the response index data and the data of each response index is scaled and compressed in the interval $(0,1)$. The relationship between the amount of water and fertilizer and the relative value of each response index of drip irrigation grape can be obtained (see Figure 1). 

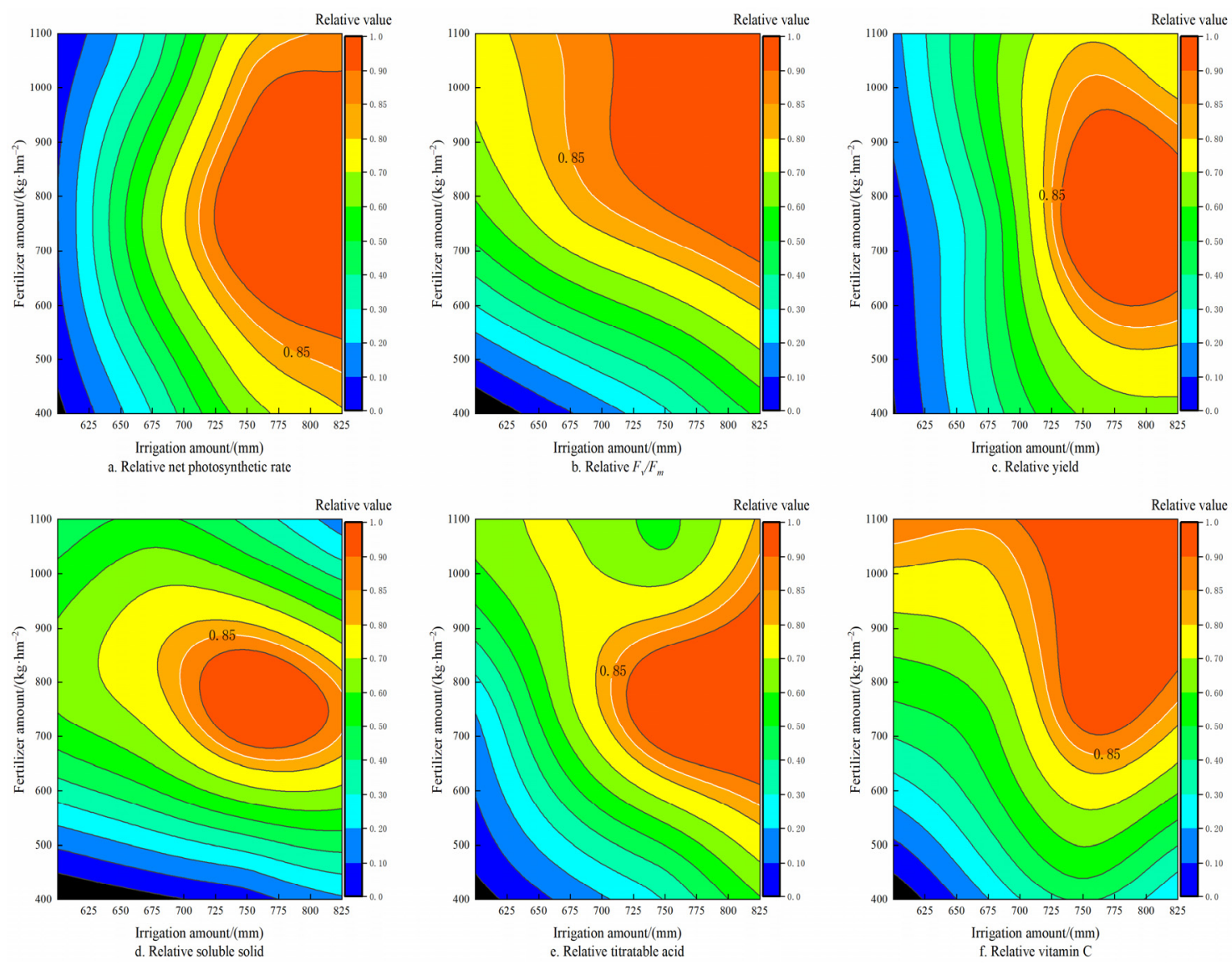

Figure 1. Relationship between the amount of water and fertilizer and the relative value of each response index of drip irrigation grapes. Note: The white line in the figure is the relative value of each index and is a 0.85 contour.

In the comprehensive evaluation of $P_{n}, F_{v} / F_{m}$, yield, soluble solids, titratable acid, and vitamin $\mathrm{C}$ indicators of drip irrigation, the indicators in Figure 1 were 0.90, 0.85, and 0.80. The acceptable area is comprehensively evaluated. As can be seen from Figure 1, there are overlapping areas for each indicator in the 0.90 acceptable area, but the overlapping area is relatively small and slightly deviated from the relative value of the soluble solids. In the 0.80 acceptable area, there are also overlapping areas within the indicators, but the overlap area is too large to cause deviation from the extreme value. Overlapping areas of the 0.85 acceptable areas of each indicator meet the evaluation requirements.

Based on the above analysis, each response indicator $\geq 0.85$ of the maximum acceptable area is defined as a reasonably acceptable range. The 0.85 contours of each response index in Figure 1 are projected and combined and a comprehensive evaluation analysis chart of each response index can be obtained (see Figure 2). It can be seen from Figure 2 that the irrigation range of each response index reaching a $\geq 0.85$ maximum is $725-825 \mathrm{~mm}$, and the fertilization interval is $684-889 \mathrm{~kg} \mathrm{ha}^{-1}$, of which $\mathrm{N}\left(273.6-355.6 \mathrm{~kg} \mathrm{ha}^{-1}\right)-\mathrm{P}_{2} \mathrm{O}_{5}\left(136.8-177.8 \mathrm{~kg} \mathrm{ha}^{-1}\right)-\mathrm{K}_{2} \mathrm{O}\left(273.6-355.6 \mathrm{~kg} \mathrm{ha}^{-1}\right)$. W3F2 (irrigation volume $750 \mathrm{~mm}$, fertilization volume $750 \mathrm{~kg} \mathrm{ha}^{-1}$ ) is also treated in this area. 


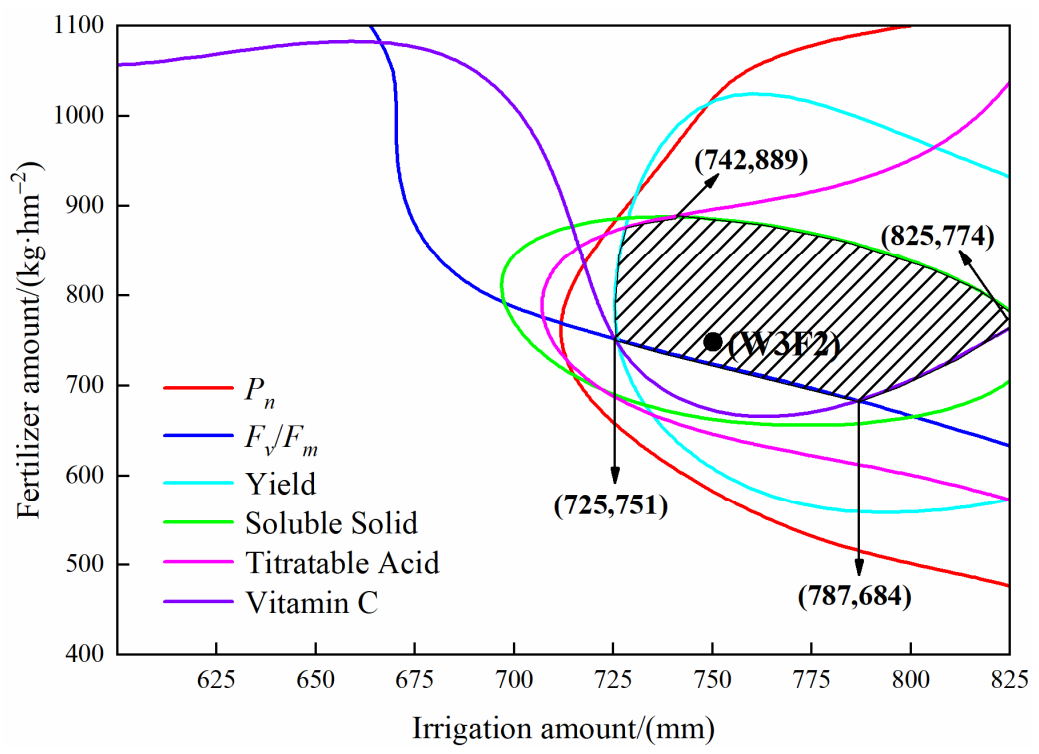

Figure 2. Comprehensive evaluation of each response index of drip irrigation grapes. Note: The grid area in the figure is a reasonable acceptable range for each response indicator to be greater than the 0.85 maximum contour. The black point is the W3F2 treatment.

\section{Discussion}

Photosynthesis is a process in which plants absorb light energy and synthesize rich organic substances, such as carbon dioxide and water to release oxygen simultaneously. During the growth and development of plants, they develop in a direction favorable for photosynthesis, thereby achieving the purpose of adapting to the surrounding growth environment [31]. Increasing photosynthesis conversion will be an important way to increase crop yields in the future [32]. This study showed that, under the same irrigation treatment, the photosynthesis indicators $P_{n}, T_{r}$, and $G_{s}$ first increased and then decreased with the increase of fertilizer application. Under the same fertilization treatment, photosynthesis indicators $P_{n}, T_{r}$, and $G_{s}$ increased with the increase of the amount of irrigation. The maximum value was obtained in thee W4F2 treatment and there was no significant difference between the W3F2 treatment and the W4F2 treatment $(p>0.05)$, while the $C_{i}$ performance was reversed and the minimum value was obtained in $\mathrm{W} 4 \mathrm{~F} 2$, showing obvious non-stomatal factors. It is indicated that water stress affected the plant photosynthesis to a certain extent and too high or too low fertilization amounts affect the photosynthesis. The appropriate water and fertilizer dosage could make the photosynthetic conversion efficiency reach a high level. This is similar to the conclusions of some scholars [33,34].

Chlorophyll fluorescence kinetics technology can detect rapid and non-invasive detection of plant photosynthetic systems under environmental stress [35]. Under normal conditions, the light energy absorbed by chlorophyll is consumed by photosynthetic electron transport, chlorophyll fluorescence emission, and heat dissipation pathways. Crop stress by growing environment may affect photosynthetic electron transport and cause damage to the chlorophyll structure. In this study, $F_{v} / F_{m}$ were used as probes for good indicators of environmental stress and photoinhibition. The $F_{v} / F_{m}$ value was positively correlated with water and fertilizer use and there was no significant difference between the W4F3 and W3F3 treatments. It is indicated that increasing the amount of water and fertilizer can increase the $F_{v} / F_{m}$, and, in the influence of $F_{v} / F_{m}$, the fertilization factor is greater than the irrigation factor, indicating that increasing the amount of fertilizer can alleviate the photoinhibition and photodamage caused by water stress. There was no significant difference between treatment of the W4F3 and W3F3 treatments. Too little and excessive application of water and fertilizer had antagonistic effects on $q^{P}$ and ФPSII. Under the condition of water and fertilizer stress, the crop was restricted by photosynthetic substrate, which reduced the light energy that crops could use. Most of the absorbed 
light quantum are lost in the form of heat energy and are not used for photosynthesis. The physiological activities of crops are inhibited, resulting in a decrease in photosynthesis and photochemical quenching coefficient, which in turn shows a decrease in the actual photochemical quantum efficiency of PSII. The degree of inhibition increases. It is indicated that the reasonable amount of water and fertilizer can increase the maximum yield of primary photochemistry, potential photochemical efficiency of PSII, the photochemical quenching coefficient, and the PSII actual photochemical quantum efficiency, which is related to similar previous results [36,37].

Crop yield and quality indicators are the main factors directly affecting economic income. Reasonable water and fertilizer use can increase crop yield and quality and achieve the goal of low input and high output in agricultural production. Crop yield is positively correlated with irrigation amount and fertilization amount within a certain range [38]. Exceeding a certain level of irrigation and fertilization will reduce yield and quality of crops. Increasing irrigation capacity will reduce irrigation water use efficiency [39]. Fertilizer use efficiency decreases as the amount of fertilizer applied increases [40]. This study showed that water and fertilizer interaction had significant effects on yield, quality, and water and fertilizer use efficiency. The yield reached the maximum in the W3F2 treatment and the yield increased by $29.76 \%$, compared with the minimum yield of W1F1. The quality index reached a superior level in the W3F2 treatment, indicating the reasonable amount of water and fertilizer can improve the crop yield and quality and achieve the purpose of improving quality and efficiency. The findings are similar to previous studies.

The optimization of water and fertilizer management aims to ensure that the crop maintains a good physiological growth state to achieve a high quality and a high yield, while reducing the amount of water and fertilizer to achieve efficient production, achieving the goal of coordinated development of economic and environmental benefits and achieving the sustainable development of agricultural production. In this study, the net photosynthetic rate of the physiological indicators of drip irrigation grapes, the maximum yield of primary photochemistry, and the yield and quality index were used as comprehensive evaluation indicators. Principal component analysis and grey correlation analysis were used to comprehensively quantify the evaluation indexes of different water and fertilizer treatments. The results of the analytical methods show that the W3F2 treatment is the best. Using multiple regression analysis combined with spatial analysis method, the comprehensive evaluation of grape drip irrigation water and fertilizer is the following: Irrigation amount $725-825 \mathrm{~mm}$; fertilization amount $684-889 \mathrm{~kg} \mathrm{ha}^{-1}$, of which $\mathrm{N}\left(273.6-355.6 \mathrm{~kg} \mathrm{ha}^{-1}\right)-\mathrm{P}_{2} \mathrm{O}_{5}\left(136.8-177.8 \mathrm{~kg} \mathrm{ha}^{-1}\right)$ - $\mathrm{K}_{2} \mathrm{O}\left(273.6-355.6 \mathrm{~kg} \mathrm{ha}^{-1}\right)$. W3F2 treatment is also in this range. Three comprehensive evaluation methods are used to comprehensively quantify the response of different water and fertilizer treatment indicators, not only to quantitatively evaluate the optimal water and fertilizer treatment, but also to provide a suitable range of water and fertilizer use, which can provide a basis for optimal management of grape drip irrigation water and fertilizer in extreme arid areas.

Through the experimental study, the suitable range of water and fertilizer for grape drip irrigation in an extreme arid area was given. However, there are still some following aspects to be studied: (1) The test is carried out for a short period and the obtained results need to be tested for long-term tests; (2) The optimal water and fertilizer treatment obtained by the test is concentrated in high-water fertilizer, in this range, water and fertilizer treatment should be added to further determine the appropriate amount of water and fertilizer.

\section{Conclusions}

In this paper, we could draw the following three main conclusions:

(1) Based on principal component analysis and grey correlation analysis, the net photosynthetic rate $\left(P_{n}\right)$ of grape drip irrigation response, the maximum photochemical yield $\left(F_{v} / F_{m}\right)$, yield, irrigation water use efficiency, fertilizer partial productivity, soluble solids, titratable acid, and vitamin $C$ were comprehensively evaluated and the optimal water and fertilizer treatment was W3F2 (irrigation volume $750 \mathrm{~mm}$, fertilization volume $\left.750 \mathrm{~kg} \mathrm{ha}^{-1}\right)$, of which $\mathrm{N}\left(300 \mathrm{~kg} \mathrm{ha}^{-1}\right)-\mathrm{P}_{2} \mathrm{O}_{5}\left(150 \mathrm{~kg} \mathrm{ha}^{-1}\right)-\mathrm{K}_{2} \mathrm{O}$ 
(300 $\mathrm{kg} \mathrm{ha}^{-1}$ ). Using multiple regression analysis combined with a spatial analysis method, the comprehensive evaluation of grape drip irrigation water and fertilizer is the following: Irrigation amount 725-825 mm; fertilization amount 684-889 $\mathrm{kg} \mathrm{ha}^{-1}$, of which $\mathrm{N}\left(273.6-355.6 \mathrm{~kg} \mathrm{ha}^{-1}\right)-\mathrm{P}_{2} \mathrm{O}_{5}$ $\left(136.8-177.8 \mathrm{~kg} \mathrm{ha}^{-1}\right)-\mathrm{K}_{2} \mathrm{O}\left(273.6-355.6 \mathrm{~kg} \mathrm{ha}^{-1}\right)$.

(2) Under different water and fertilizer treatments, the physiological, yield, and quality indexes of drip-irrigated grapes are different and the numerical changes are regular. The interaction of water and fertilizer has a significant impact on the response indicators. Reasonable water and fertilizer dosage provide an excellent growth environment for drip-irrigated grapes and has a positive impact on the response indicators.

(3) The relative photosynthesis and chlorophyll fluorescence index of grapes under drip irrigation changed regularly with the advance of the growth period, under different water and fertilizer treatments.

Author Contributions: Conceptualization, Z.W.; methodology, H.D.; software, Y.H.; validation, Y.W. and Y.D.; formal analysis, Y.H.; investigation, J.Z.; resources, Z.W.; data curation, Y.H. and Y.W.; writing-original draft preparation, Y.H.; writing-review and editing, Y.H.; visualization, J.Z.; supervision, W.L.; project administration, W.L.; funding acquisition, Z.W.

Funding: This research received no external funding.

Acknowledgments: We are grateful for the financial support from the Academician of the Chinese Academy of Engineering consults and research project "China Daejeon Drip Irrigation Development Strategy Research (2018-XY-36)" and the Water-saving Irrigation Experiment Project of the Corps "Study on the Grape Crop Coefficient (Kc) and Irrigation System in the Thirty Division Hami District (BTJSSY-201805)".

Conflicts of Interest: The authors declare no conflict of interest.

\section{References}

1. Bai, Y. Study on Water Requirement Rule of Grown-Up Grapes and Micro Irrigation Water-Saving Technology in Extreme Arid Region; Xinjiang Agricultural University: Ürümqi, China, 2011.

2. Yang, H.; Wang, Z.; He, X.; Tan, M.; Xiao, H. Experimental Study on Water Consumption Characteristics of Grape under Drip Irrigation Condition in Extremely Arid Regions. Available online: http:/ /kns.cnki.net/ KCMS $/$ detail $/$ detail.aspx?dbcode=CJFQ\&dbname=CJFD2011\&filename $=J S G U 201102008 \& v($ accessed on 6 April 2019).

3. Yang, H. Study on Water Consumption Law and Irrigation Scheduling of the Grape under Drip Irrigation in Turpan-KumulBasin; Shihezi University: Shihezi, China, 2011.

4. Feike, T.; Ling, Y.K.; Mamitimin, Y.; Nan, H.; Lin, L.; Abdusalih, N.; Xiao, H.; Doluschitz, R. Determinants of cotton farmers' irrigation water management in arid Northwestern China. Agric. Water Manag. 2017, 187, 1-10. [CrossRef]

5. Elmi, A.A.; Madramootoo, C.; Egeh, M.; Hamel, C. Water and Fertilizer Nitrogen Management to Minimize Nitrate Pollution from a Cropped Soil in Southwestern Quebec, Canada. Water Air Soil Pollut. 2004, 151, 117-134. [CrossRef]

6. Hebbar, S.S.; Ramachandrappa, B.K.; Nanjappa, H.V.; Prabhakar, M. Studies on NPK drip fertigation in field grown tomato (Lycopersicon esculentum Mill.). Eur. J. Agron. 2004, 21, 117-127. [CrossRef]

7. Mahajan, G.; Chauhan, B.S.; Timsina, J.; Singh, P.P.; Singh, K. Crop performance and water- and nitrogen-use efficiencies in dry-seeded rice in response to irrigation and fertilizer amounts in northwest India. Field Crops Res. 2012, 134, 59-70. [CrossRef]

8. Badr, M.A.; El-Tohamy, W.A.; Zaghloul, A.M. Yield and water use efficiency of potato grown under different irrigation and nitrogen levels in an arid region. Agric. Water Manag. 2012, 110, 9-15. [CrossRef]

9. Gheysari, M.; Loescher, H.W.; Sadeghi, S.H.; Mirlatifi, S.M.; Zareian, M.J.; Hoogenboom, G. Chapter Three-Water-Yield Relations and Water Use Efficiency of Maize Under Nitrogen Fertigation for Semiarid Environments: Experiment and Synthesis. Adv. Agron. 2015, 130, 175-229.

10. Haefele, S.M.; Jabbar, S.M.A.; Siopongco, J.D.L.C.; Tirol-Padre, A.; Amarante, S.T.; Cruz, P.C.S.; Cosico, W.C. Nitrogen use efficiency in selected rice (Oryza sativa L.) genotypes under different water regimes and nitrogen levels. Field Crops Res. 2008, 107, 137-146. 
11. Kiani, M.; Gheysari, M.; Mostafazadeh-Fard, B.; Majidi, M.M.; Karchani, K.; Hoogenboom, G. Effect of the interaction of water and nitrogen on sunflower under drip irrigation in an arid region. Agric. Water Manag. 2016, 171, 162-172.

12. Pan, J.; Liu, Y.; Zhong, X.; Lampayan, R.M.; Singleton, G.R.; Huang, N.; Liang, K.; Peng, B.; Tian, K. Grain yield, water productivity and nitrogen use efficiency of rice under different water management and fertilizer-N inputs in South China. Agric. Water Manag. 2017, 184, 191-200.

13. Gou, L.; Jie, V.; Han, C.L.; Zhao, R.H.; Zhang, W.; Yang, X. Effects of nitrogen rates on photosynthetic characteristics and yield of high-yielding cotton in Xinjiang. Plant Nutr. Fertil. Sci. 2004, 10, 488-493.

14. Cheng, M.; Hao, Z.; Yang, S.; Jiao, X.; Fan, H. The interactive impact of water and nitrogen on greenhouse green pepper under film-mulched drip irrigation. J. Irrig. Drain. 2018, 37, 50-56, 68.

15. Wang, X.; Du, C.; Xing, J.; Xing, Y. Effects of irrigation and fertilization on fruit quality of greenhouse tomatoes:principal component analysis. Mol. Plant Breed. 2017, 15, 698-704.

16. Xu, Y. Study on Effects of Water and Fertilizer Coupling on Growth, Development and Soil Environment of Lettuce in Solar-Greenhouse; Jilin University: Changchun, China, 2011.

17. Wei, Z. Effects of Water and Fertilizer on the Physiological Characteristics of Plant and Soil Environments of Cucumber and Tomato in Greenhouse; Northwest A\&F University: Yangling, China, 2009.

18. Jiang, J.; Qu, F.; Su, C.; Yang, J.; Yu, J.; Hu, X. Effects of different water and fertilizer coupling on yield and quality of cucumber and partial factor productivity of fertilizer. Sci. Agric. Sin. 2019, 52, 86-97.

19. Xing, Y.; Zhang, F.; Wu, L.; Fan, J.; Zhang, Y.; Li, J. Determination of optimal amount of irrigation and fertilizer under drip fertigated system based on tomato yield, quality, water and fertilizer use efficiency. Trans. Chin. Soc. Agric. Eng. 2015, 31, 110-121.

20. Thompson, T.L.; Doerge, T.A.; Godin, R.E. Nitrogen and water interactions in subsurface drip-irrigated cauliflower: II. Agronomic, economic, and environmental outcomes. Soil Sci. Soc. Am. J. 2000, 64, 412-418. [CrossRef]

21. Wang, Z.; Quan, L.; He, J. Effect of water and fertilizer coupling on water consumption and yield of drip irrigation grape in extreme arid region. Water Sav. Irrig. 2014, 13-15, 18. [CrossRef]

22. Zhang, X. Effects of Deep Pit Seepage Fertilization System on Soil Nutrients and Growth Characteristics of Adult Grapes. Master's Thesis, Xi'an University of Technology, Xi'an, China, 2018.

23. Wassink, E.C. Chlorophyll fluorescence and photosynthesis. Adv. Enzymol. Relat. Subj. Biochem. 1951, $11,91$. [PubMed]

24. Roháček, K. Chlorophyll Fluorescence Parameters: The Definitions, Photosynthetic Meaning, and Mutual Relationships. Photosynthetica 2002, 40, 13-29. [CrossRef]

25. Kuslu, Y.; Sahin, U.; Kiziloglu, F.M.; Memis, S. Fruit Yield and Quality, and Irrigation Water Use Efficiency of Summer Squash Drip-Irrigated with Different Irrigation Quantities in a Semi-Arid Agricultural Area. J. Integr. Agric. 2014, 13, 2518-2526. [CrossRef]

26. Ierna, A.; Pandino, G.; Lombardo, S.; Mauromicale, G. Tuber yield, water and fertilizer productivity in early potato as affected by a combination of irrigation and fertilization. Agric. Water Manag. 2011, 101, 35-41. [CrossRef]

27. Badr, M.A.; Hussein, S.D.A.; El-Tohamy, W.A.; Gruda, N. Nutrient uptake and yield of tomato under various methods of fertilizer application and levels of fertigation in arid lands. Gesunde Pflanz. 2010, 62, 11-19.

28. Markov, I.; Arampatzis, A.; Crestani, F. Unsupervised linear score normalization revisited. In Proceedings of the 35th International ACM SIGIR Conference on Research and Development in Information Retrieval, Portland, OR, USA, 12-16 August 2012.

29. Genty, B.; Briantais, J.M.; Baker, N.R. The relationship between the quantum yield of photosynthetic electron transport and quenching of chlorophyll fluorescence. BBA Gen. Subj. 1989, 990, 87-92. [CrossRef]

30. Cechin, I. Photosynthesis and Chlorophyll Fluorescence in Two Hybrids of Sorghum under Different Nitrogen and Water Regimes. Photosynthetica 1998, 35, 233-240.

31. Anselmi, S.; Chiesi, M.; Giannini, M.; Manes, F.; Maselli, F. Estimation of Mediterranean forest transpiration and photosynthesis through the use of an ecosystem simulation model driven by remotely sensed data. Glob. Ecol. Biogeogr. 2010, 13, 371-380.

32. Zhu, X.G.; Long, S.P.; Ort, D.R. Improving Photosynthetic Efficiency for Greater Yield. Annu. Rev. Plant Biol. 2010, 61, 235-261. [CrossRef] [PubMed] 
33. Quan, L.; Zheng, X.; Wang, Z.; Pei, L. Effect of water-nitrogen coupling on photosynthesis and soil water use of oil sunflower in drip-irrigated multiple cropping system. J. Nucl. Agric. Sci. 2016, 30, 1021-1029. [CrossRef]

34. Boyer, J.S. Plant productivity and environment. Science 1982, 218, 443-448. [CrossRef]

35. White, A.J.; Critchley, C. Rapid light curves: A new fluorescence method to assess the state of the photosynthetic apparatus. Photosynth. Res. 1999, 59, 63-72. [CrossRef]

36. Wu, F.Z.; Bao, W.K.; Li, F.L.; Wu, N. Effects of water stress and nitrogen supply on leaf gas exchange and fluorescence parameters of Sophora davidii seedlings. Photosynthetica 2008, 46, 40-48.

37. Shangguan, Z.; Shao, M.; Jens, D. Effects of Nitrogen Nutrition and Water Deficit on Net Photosynthetic Rate and Chlorophyll Fluorescence in Winter Wheat. J. Plant Physiol. 2000, 156, 46-51. [CrossRef]

38. Liu, K.; Zhang, T.Q.; Tan, C.S.; Astatkie, T. Responses of Fruit Yield and Quality of Processing Tomato to Drip-Irrigation and Fertilizers Phosphorus and Potassium. Agron. J. 2011, 103, 1339-1345.

39. Singandhupe, R.B.; Rao, G.G.S.N.; Patil, N.G.; Brahmanand, P.S. Fertigation studies and irrigation scheduling in drip irrigation system in tomato crop (esculentum L.). Eur. J. Agron. 2003, 19, 327-340.

40. Zhang, T.Q.; Liu, K.; Tan, C.S.; Warner, J.; Wang, Y.T. Processing Tomato Nitrogen Utilization and Soil Residual Nitrogen as Influenced by Nitrogen and Phosphorus Additions with Drip-Fertigation. Soil Sci. Soc. Am. J. 2011, 75, 738-745. [CrossRef]

(C) 2019 by the authors. Licensee MDPI, Basel, Switzerland. This article is an open access article distributed under the terms and conditions of the Creative Commons Attribution (CC BY) license (http://creativecommons.org/licenses/by/4.0/). 